\title{
Repo Markets Across the Atlantic: Similar but unalike
}

\author{
Songjiwen $\mathrm{Wu}^{*}$ \\ Hossein Nabilou**
}

\begin{abstract}
This paper sketches the key differences in the EU and the U.S. repo markets to inform the policy recommendations for harmonization and standardization of rules governing repo contracts put forward by the international financial fora and standard setters. In so doing, it examines three main aspects of the repo markets. First, it highlights the differences in the legal framework governing repo markets, such as legal construction of repo contracts, special insolvency treatment, and legal treatment of the reuse of collateral. Second, it discusses the composition, structure and organization of the repo markets, such as differences in the composition of repo participants, maturity of repos and the composition of the underlying collateral in repo contracts. Finally, it investigates the differences in the issues related to the market infrastructure of repo markets such as differences in the clearing and collateral management stages. The main finding of this paper is that in spite of significant efforts to standardize and harmonize repo markets as well as their applicable legal framework in the past, there remains significant differences across the Atlantic. Such differences in the legal framework, composition, structure and organization of repo markets and repo markets infrastructure would require differential and more nuanced approach to regulating repo markets than what is pursued by the current international financial standard setters.
\end{abstract}

Keywords: Repurchase agreement (repo), Tri-party repo, Central counterparty clearing (CCP), DoddFrank Act, European Market Infrastructure Regulation (EMIR), Securities Financing Transactions and Reuse Regulation (SFTR)

JEL Classification: F3, G1, G2, G3, K2, N2

\footnotetext{
* Mag. iur Candidate, University of Heidelberg; Faculty of Law; Bachelor of Laws (LL.B.), Beijing Foreign Studies University; Admitted to the bar in China; E-mail: songjiwen.wu@ stud.uni-heidelberg.de

** Postdoc in Banking and Financial Law; University of Luxembourg; Faculty of Law, Economics and Finance; LL.M., University of Pennsylvania Law School; E-mail: hossein.nabilou@uni.lu
} 


\section{Introduction}

The vulnerabilities in the wholesale funding and in particular short-term (overnight) repurchase agreement (repo) markets were a significant source of systemic risk in the Global Financial Crisis (GFC). ${ }^{1}$ In the aftermath of the crisis, international regulatory fora as well as supra-national and national regulators on both sides of the Atlantic were given the arduous task of reforming the legal environment of the short-term financing channels perceived to be at the heart of the crisis. Since the largest European banks obtain collateral using Securities Financing Transactions (SFTs) (including repos) rather than using derivatives, ${ }^{2}$ repo transactions - as the main instrument for short-term wholesale funding ${ }^{3}$ - occupies the epicenter of the regulatory initiatives to address the fragilities in the short-term funding markets.

The excessive dependence on short-term wholesale funding contributed to the failure of some of the largest investment and commercial banks, such as Bear Stearns, Lehman Brothers, and Northern Rock. ${ }^{4}$ In addition to maturity and liquidity transformation, repo transactions involve varying degrees of financial leverage depending on the level of haircuts or initial margins. ${ }^{5}$ The levered maturity mismatch combined with the lack of access to government safety nets,

\footnotetext{
${ }^{1}$ Gary B. Gorton and Andrew Metrick, "Securitized Banking and the Run on Repo," Journal of Financial Economics 104, no. 3 (2012).; Gary B. Gorton, Slapped by the Invisible Hand: The Panic of 2007 (New York: Oxford University Press, 2010). ${ }^{2}$ The data on collateral flows show that the at the beginning of 2013, the gross collateral flows (collateral posted and received) though repos amounted to $€ 5.8$ trillion, whereas collateral flows through derivatives stood at $€ 340$ billion. The total gross collateral flows stood at $€ 8.5$ trillion. 6. See Table 2 of Keller et al. (2014). Quoted from ESRB to ESMA opinion on securities financing transactions, pp. 7-8

${ }^{3}$ European Systemic Risk Board, "Esrb Opinion to Esma on Securities Financing Transactions and Leverage under Article 29 of the Sftr," (2016), 7.

${ }^{4}$ Viktoria Baklanova, Adam Copeland, and Rebecca McCaughrin, "Reference Guide to Us Repo and Securities Lending Markets," in Federal Reserve Bank of New York Staff Reports (New York: Federal Reserve Bank of New York, 2015), 3337. See also: The Financial Crisis Inquiry Commission, "The Financial Crisis Inquiry Report: Final Report of the National Commission on the Causes of the Financial and Economic Crisis in the United States," (Washington, D.C.2011).

${ }^{5}$ Board, "Securities Lending and Repos: Market Overview and Financial Stability Issues- Interim Report of the Fsb Workstream on Securities Lending and Repos." P. 8
} 
catapulted repo markets, as part of the shadow banking system, into the center of the fragility of the financial system. ${ }^{6}$

Indeed, the subprime-mortgage crisis is described as a "run on repo", which is comparable to a traditional bank run in modern securitized banking with repo as a funding source. ${ }^{7}$ Gorton and Metrick show that during the GFC, the average haircut of structured securities peaked, which rendered some of them unacceptable as collateral (i.e., a 100\% haircut) in repo markets. Critics point out that this comparison is flawed due to its failure to include U.S. treasuries and agency bonds, which are the largest pool of collateral, or to include any evidence of run on tri-party repos, which constitute the largest part of repo markets in the U.S. ${ }^{8}$ Therefore, according to the critics, the impact of rising haircuts was largely overestimated. For example, Krishnamurthy, Nagel and Orlov only observed moderate increase in haircuts for structured securities and corporate bonds, ranging from 3-4\% to 5-7\% in $2009 .{ }^{9}$ Although the impact of repos in financial markets might be overstated, since repos allow for leveraged maturity and liquidity transformation without access to government safety nets, they lie at the heart of the fragility of the shadow banking system. ${ }^{10}$

\footnotetext{
${ }^{6}$ For a definition of shadow banking system; See: Hossein Nabilou and Alessio Pacces, "The Law and Economics of Shadow Banking," in Research Handbook in Shadow Banking, ed. Iris H. Chiu (forthcoming 2017).; Stijn Claessens and Lev Ratnovski, "What Is Shadow Banking?," IMF Working Paper (2014).; International Monetary Fund, "Global Financial Stability Report: Risk Taking, Liquidity, and Shadow Banking: Curbing Excess While Promoting Growth," (Washington, DC: International Monetary Fund, October 2014), 68-72.

To see how government extended support to the shadow banking (especially broker dealers) and hence create new sets of government-backed shadow banking system, see Zoltan Pozsar, "Shadow Banking: The Money View," Office of Financial Research Working Paper (2014). Gorton and Metrick, "Securitized Banking and the Run on Repo," 1.; Gorton, Slapped by the Invisible Hand: The Panic of 2007.; Gary Gorton, "Shadow Banking," The RegionDecember 2010.

${ }^{7}$ Gorton and Metrick, "Securitized Banking and the Run on Repo," 1.; Gorton, Slapped by the Invisible Hand:

The Panic of 2007.; Gary Gorton, "Shadow Banking," The RegionDecember 2010.

${ }^{8}$ Krishnamurthy, Nagel, and Orlov, "Sizing up Repo."; International Capital Market Association, "Frequently

Asked Questions on Repo," ed. International Capital Market Association (ICMA) (2015), 31.;

${ }^{9}$ Krishnamurthy, Nagel, and Orlov, "Sizing up Repo," 31. In repo markets, as part of the debt markets, the market participants would rather cease to invest altogether or decline accepting certain collateral than demanding an increase in initial margin. Ibid.

${ }^{10}$ Board, "Securities Lending and Repos: Market Overview and Financial Stability Issues- Interim Report of the Fsb Workstream on Securities Lending and Repos." P. 8

To see how government extended support to the shadow banking (especially broker dealers) and hence create new sets of government-backed shadow banking system, see Pozsar, "Shadow Banking: The Money View."
} 
This paper is the first comparative study of the repo markets in the U.S. and the EU systemically contrasting different aspects of the repo markets across the Atlantic. Such an exercise is necessary for the formulation of policy recommendations at the international level particularly when international standard setters are determined to address the vulnerabilities of the shadow banking system. This paper proceeds as follows: first it studies the differences in the legal framework governing repo transactions. Second, it focuses on the composition, structure and organization of repo markets to uncover the subtle differences in the repo terms, market participants and the underlying collateral backing repo transactions. Third, it examines the differences in the market infrastructure within which repos are being cleared and settled which can potentially have dramatic impact on financial stability. Finally, the paper discusses the impact of the Basel III leverage and liquidity requirements on repo markets. The main source of data used in this paper are the ICMA survey for the European repo markets and the website of the Federal Reserve Bank of New York for the U.S. market.

\section{Differences in the U.S. and EU repo markets}

The focus of international efforts and transatlantic regulatory reforms have been on addressing the fragility of the shadow banking (as well as banking) system by incenting financial institutions to reduce their leverage, improve their liquidity conditions, and specifically reduce their reliance on short-term wholesale funding. One of the targets of regulation therefore was repo transactions, ${ }^{11}$ about which the Financial Stability Board (FSB) has issued several recommendations. However, a careful examination of the market structure and legal structure of the repo markets across the Atlantic reveals their fundamental differences and raises doubts

\footnotetext{
${ }^{11}$ In the securities lending, the lender passes the legal title of securities to the borrower for the life of the loan. When securities are returned to the lender, the lender again retains the title to the loan. Even though the lender does not have legal title to the securities lent, the economic benefits of corporate actions (stock splits, income and dividends) will accrue to the lender. However, in case of equity securities, the lender will not retain voting rights of the securities it has lent for the duration of the term of the loan.
} 
about whether a uniform regulatory approach is a right path to take. ${ }^{12}$ Thus, understanding the distinction in the market structure of repo markets in the EU and the one in the U.S. is of paramount importance for regulation of both markets, as well as other developing financial markets.

\section{Differences in legal construction and applicable law}

From an economic point of view, a repo is equivalent to a secured loan. The lender (buyer) in a repo receives the underlying securities as collateral while the borrower (seller) commits to buy the same asset back in the future. Under normal circumstances, the buyer will earn a return after reselling the asset back to the repo seller in the closing leg at a higher price. Thanks to its simple legal structure, repos are widely accepted across common-law as well as civil-law jurisdictions.

A typical repo transaction can be chronologically divided into multiple steps. ${ }^{13}$ The parties should first reach an agreement as to the key terms and conditions, such as parties, maturity date, securities and cash amount, haircuts, repo interest and so on. This first step is referred to as "trading". After this agreement has been reached, the parties will each examine their remaining obligation to deliver cash in the same currency and/or the same security to each other and work out a net volume on a daily basis. They may also be bound by legal obligation to clear this transaction multilaterally. After this 'clearing' stage, the seller keeps the security on its book while adding a loan to its liabilities and the received cash as an asset. The purchased asset does not appear on the balance sheet of the buyer since the seller agrees to buy it back. At last, the parties will manage the underlying collateral. ${ }^{14}$

In Europe, a repurchase agreement transfers legal title to collateral from the seller to the buyer. In other words, a repo in Europe is a true sale; hence the name 'title transfer (financial)

\footnotetext{
${ }^{12}$ See Eddy Wymeersch, "Shadow Banking and Systemic Risk," European Banking Institute Working Paper Series No. 1 (2017). P. 19.

${ }^{13}$ Ibid., p. 41.

${ }^{14}$ As will be explained in this paper, one of the most significant differences between the European and the U.S. Repo market lies in this "collateral management" stage.
} 
collateral arrangement' (TTCA). ${ }^{15}$ This renders repo a cheap source of funding and liquidity for repo market participants. The repo seller can use the cash it has borrowed to buy the same or similar assets in the market (i.e., to finance its long positions), meanwhile, the repo buyer can reuse the collateral to refinance itself in a similar fashion during the life of the repo (i.e., to cover its short positions). ${ }^{16}$ Theoretically, this process could repeat several times until profitability is exhausted by initial margining or credit limits.

However, in the U.S., under the New York State law, since transferring title to collateral is difficult, the collateral is pledged, but it is exempt from certain provisions of the U.S. Bankruptcy Code that apply to pledges (automatic stay). ${ }^{17}$ Nonetheless, the pledgee or the buyer is given a general right of use of collateral, which is also known as rehypothecation. ${ }^{18}$ In spite of this legal nuance, this arrangement effectively - and in economic terms - is equivalent to an outright sale. Under the New York State law, repos include a fall-back provision. Namely, if the buyer's right to collateral proves to be unenforceable, the repo will be recharacterized as secured lending. However, English law (and the EU law) ${ }^{19}$ does not allow such recharacterization. ${ }^{20}$

Therefore, in the EU, the TTCA form used for repo transactions does not per se necessitate the use of bankruptcy safe harbors for repo transactions, because such transactions are already concluded as a true sale transaction (title transfer) rather than a secured transaction. However, it seems that due to the differential treatments of such transactions in different Member States and potential conflicts stemming from such frictions, bankruptcy safe harbors are already

\footnotetext{
${ }^{15}$ In Europe, there are both "title transfer financial collateral arrangement" and "security financial collateral arrangement" (Art. 2, Directive 2002/47/EC), but it seems that the majority of repos are in the form of TTCAs. For a difference between traditional collateralized lending and TTCA, see; Joanna Benjamin, Guy Morton, and Michael Raffan, "The Future of Securities Financing," Law and Financial Markets Review 7, no. 1 (2013): 5-6.

${ }^{16}$ See FCD and SFTR

${ }^{17}$ For a general overview of the

${ }^{18}$ For the subtleties in the difference between the right of use and rehypothecation, see:

${ }^{19}$ See prohibition of recharacterization in FCD. Directive 2002/47/EC Art. 6

${ }^{20}$ Most probably because there is no need for such a provision.
} 
included in the Settlement Finality Directive (SFD) ${ }^{21}$ and the Financial Collateral Arrangements Directive (FCD). ${ }^{22}$

Efforts to standardize and harmonize repo transactions have been underway well before the GFC. For example, industry initiatives through self-regulatory organizations (SROs), such as the International Capital Market Association (ICMA), Securities Industry and Financial Markets Association (SIFMA), and International Swaps and Derivatives Association (ISDA) have been relatively successful in achieving certain degrees of standardization in the design, governance, and legal framework of such transactions. ${ }^{23}$ For instance, the ICMA (and its predecessor institutions) played a significant role in pushing governments to adopt bankruptcy safe harbors for repos and certain types of derivatives transactions with financial counterparties.

Despite such efforts toward standardization, the repo markets in Europe and in the U.S. operate differently in various aspects and many repo transactions are subject to local rules and regulations of specific jurisdictions. This is the case especially in Europe where those transactions are still governed and regulated by the Member State laws, subject to varying degrees of harmonization at the EU level. In addition, there are still frictions in the legal regime for repos even within the international self-regulatory frameworks. For example, the choice of different master agreements amounts to different governing laws across the Atlantic. In Europe, the Global Master Repurchase Agreement (GMRA) drafted and continuously updated by the ICMA is often executed between the lender and the borrower, the governing law of which is the English law. ${ }^{24}$ This master agreement also has a major impact on the U.S. repo market when the repo transaction involves an international counterparty. However, for

\footnotetext{
${ }^{21}$ Directive 98/26/EC of the European Parliament and of the Council of 19 May 1998 on settlement finality in payment and securities settlement systems, OJ L 166, 11.6.1998, p. 45-50

${ }^{22}$ Directive 2002/47/EC of the European Parliament and of the Council of 6 June 2002 on financial collateral arrangements

${ }^{23}$ This has played a major role in liquidity in the market for such instruments.

${ }^{24}$ GMRA Version 2011, para. 17.
} 
U.S. domestic repos, the SIFMA Master Agreement, which is governed by New York state law, ${ }^{25}$ is prevalent.

\section{Special bankruptcy treatment}

One of the most controversial aspects of Securities Financing Transactions (SFTs) and in particular repos is the special bankruptcy treatment for such instruments. Under the New York State law, which governs SIFMA Master Repo Agreement (MRA), it could be difficult to transfer the legal title of the collateral. Therefore, the U.S. treasury and agency securities, which constitute the major part of the U.S. repo market, are given as collateral through a pledge. ${ }^{26}$ However, the U.S. Bankruptcy Code affords special treatment to Qualified Financial Contracts (QFCs) (including derivatives and repos) by exempting them from the 'automatic stay' and allowing counterparties to terminate these contracts by closing out, netting or setting off their derivatives positions and seizing the underlying collateral. ${ }^{27}$ In other words, as a nondefaulting party to a QFC, the repo buyer can in principal terminate these agreements in order to immediately dispose of the collateral in case of bankruptcy of its counterparty. ${ }^{28}$

The bankruptcy safe harbors in the U.S. and their EU equivalents embedded in the EU SFD and the FCD played an important role in the growth of shadow banking. ${ }^{29}$ In addition to the benefits that these safe harbors provide in terms of enhanced market and funding liquidity, ${ }^{30}$ they also enhance financial stability. The underlying rationale for these safe harbors for derivatives and repos was that the derivatives markets can be a source of systemic risk and

\footnotetext{
${ }^{25}$ SIFMA's MRA, Version 1996, para. 16.

${ }^{26}$ Association, "Frequently Asked Questions on Repo," 28.

27 The Safe Harbor Provisions are embedded in the following provisions: 11 U.S.C. $\$ \$ 362$ (b)(6), 362(b)(7), 362(b)(17), 546, 556, 559, $560 \& 561$ (2012). In Europe, such safe harbors are granted in the financial collateral directive. See: FCD, art8

${ }^{28}$ Adam Copeland et al., "Key Mechanics of the Us Tri-Party Repo Market," Federal Reserve Bank of New York Economic Policy Review 18, no. 3 (2012): 5.; Darrell Duffie and David A Skeel, "A Dialogue on the Costs and Benefits of Automatic Stays for Derivatives and Repurchase Agreements," (2012): 2. see 11 U.S.C. $\S 362(\mathrm{a})$.

${ }^{29}$ Gary B. Gorton and Andrew Metrick, "Regulating the Shadow Banking System," Brookings Papers on Economic Activity (2010): 266.

${ }^{30}$ See Philipp Paech, "The Value of Insolvency Safe Harbours," LSE Legal Studies Working Paper No. 9/2015 (2015).; Nathan Goralnik, "Bankruptcy-Proof Finance and the Supply of Liquidity," Yale Law Journal 122 (2012).
} 
this exemption would be necessary to prevent the risks of contagion and systemic risk. ${ }^{31}$ Exempting such contracts from bankruptcy stays would increase market confidence provided by guaranteeing the lenders their right to the collateral, thereby mitigating the possibility of a debtor's bankruptcy resulting in systematic failure.

However, repo runs, as one of the main contagion channels in the GFC, ignited a contentious debate on the special bankruptcy regime for repos. ${ }^{32}$ It is argued that such safe harbors increase the likelihood of fire sales and collateral crises. ${ }^{33}$ Further evidence suggest that the role of closeout and netting in reducing systemic risk is far from straightforward. ${ }^{34}$ In other words, although this exemption produces numerous benefits and is necessary for the wellfunctioning of financial markets, ${ }^{35}$ it encourages the run on financial institutions by incenting counterparties to close-out or net derivatives contracts at the first signals of insolvency of a financial firm.

An additional downside to bankruptcy safe harbors is that they amplify the moral hazard risk. As explained by Duffie and Skeel, safe harbors undermine the parties' incentive to closely monitor their debtors' financial condition by giving the counterparty the guarantee to their collateral, despite the fact that the collateral could experience a substantial loss in value, rendering the majority of their exposures unsecured as was the case in the Lehman bankruptcy. ${ }^{36}$ Furthermore, if lenders believe that the government would bail out their debtors in the event of distress or default, a safe harbor clause will almost certainly encourage lenders to take advantage of their counterparties' too-big-to-fail status, further contributing to moral

\footnotetext{
${ }^{31}$ See for example, René M. Stulz, "Should We Fear Derivatives?," The Journal of Economic Perspectives 18, no. 3 (2004): 188.

${ }^{32}$ Gorton and Metrick, "Securitized Banking and the Run on Repo."

${ }^{33}$ Carolyn Sissoko, "The Legal Foundations of Financial Collapse," Journal of Financial Economic Policy 2, no. 1 (2010). See also Steven L. Schwarcz, "Derivatives and Collateral: Balancing Remedies and Systemic Risk," University of Illinois Law Review 2015, no. 2 (2015).

${ }^{34}$ Robert R. Bliss and George G. Kaufman, "Derivatives and Systemic Risk: Netting, Collateral, and Closeout," Journal of Financial Stability 2, no. 1 (2006).

${ }^{35}$ For why the derivatives contracts should be treated differently on efficiency-based grounds, See Franklin R Edwards and Edward R Morrison, "Derivatives and the Bankruptcy Code: Why the Special Treatment," Yale Journal on Regulation 22 (2005).

${ }^{36}$ Duffie and Skeel, "A Dialogue on the Costs and Benefits of Automatic Stays for Derivatives and Repurchase Agreements," 9., see also its fn. 10.
} 
hazard. In addition, repo transactions in the U.S. are mostly overnight and short term. Since the law recognizes repo as a QFC but not a traditional secured loan, it would incent lenders to concentrate their funds in this method of lending, rendering traditional financing methods (e.g., long terms and unsecured loans) obsolete. This would amount to a decrease in market discipline as the unsecured creditors are believed to be the watchdogs of market discipline. ${ }^{37}$

Therefore, it is argued that this safe harbor does not reduce systemic contagion, because it overlooks some intricate complexities, interconnectedness and interactions among financial institutions. The safe harbors also are considered responsible for the failure of Lehman Brothers, especially accounting for the fact that the exemptions from the automatic stay failed to prevent a run on Lehman. ${ }^{38}$ It is documented that just before the collapse of Lehman brothers, JP Morgan seized \$17 billion in Lehman's collateral and demanded an additional \$5 billion payment. ${ }^{39}$

Scholars are also divided on a wide spectrum on this contested issue. Some believe that the safe harbors should be totally repealed. ${ }^{40}$ Others believe that they should be maintained in their entirety. And a third group believes in narrowing down the scope of such safe harbors. ${ }^{41}$

\footnotetext{
${ }^{37}$ Such concerns have been paramount in the case of covered bonds, which are another form of secured lending. See European Banking Authority, "Eba Report on Eu Covered Bond Frameworks and Capital Treatment: Response to the Commission's Call for Advice of December 2013 Related to Article 503 of the Regulation (Eu) No 575/2013 and to the Esrb Recommendation E on the Funding of Credit Institutions of December 2012 (Esrb/12/2)," (London01 July 2014), 138.

${ }^{38}$ Schwarcz, "Derivatives and Collateral: Balancing Remedies and Systemic Risk."

${ }^{39}$ See Darrell Duffie, "The Failure Mechanics of Dealer Banks," Journal of Economic Perspectives 24, no. 1 (2010).

Duffie, "The Failure Mechanics of Dealer Banks." In addition, This safe harbor also encourages systemically risky market concentration on the conviction that on the default of a counterparty, the dealer would simply seize the collateral, making the dealer care less about the amount of its concentrated exposure to one counterparty. Schwarcz, "Derivatives and Collateral: Balancing Remedies and Systemic Risk."

${ }^{40}$ Stephen J Lubben, "Repeal the Safe Harbors," American Bankruptcy Institute Law Review 18 (2010).; "Derivatives and Bankruptcy: The Flawed Case for Special Treatment," University of Pennsylvania Journal of Business Law 12, no. 1 (2009).; "The Bankruptcy Code without Safe Harbors," American Bankruptcy Law Journal 84 (2010); Charles W. Mooney, "The Bankruptcy Code's Safe Harbors for Settlement Payments and Securities Contracts: When Is Safe Too Safe?," Texas International Law Journal 49 (2014).

Antinolfi et al, also find that the bankruptcy safe harbors had contributed to the growth and development of repo markers, but also this may increase the likelihood of fire sales and hence reduce the real investment in the economy. Therefore, bankruptcy policy makes face a trade-off between the reduction of the risk to the investment activities in the real economy and better liquidity of repo markets. See G. Antinolfi et al., "Repos, Fire Sales, and Bankruptcy Policy," Review of Economic Dynamics 18, no. 1 (2015).

Sissoko, "The Legal Foundations of Financial Collapse." However, given the benefits of this safe harbor, it is argued that abolishing them would so more harm than good and it would adversely affect the liquidity of financial markets. See Goralnik, "Bankruptcy-Proof Finance and the Supply of Liquidity."

${ }^{41}$ Bryan G. Faubus, "Narrowing the Bankruptcy Safe Harbor for Derivatives to Combat Systemic Risk," Duke Law Journal 59, no. 4 (2010). David Skeel and Thomas Jackson also explore the effects of transaction consistency (or "equivalent treatment of similar transactions" in bankruptcy and conclude that imposing transaction consistency on repos would have limited impact. They also have a nuanced approach to removing safe harbors. David A. Skeel and Thomas H. Jackson, "Transaction Consistency and the New Finance in Bankruptcy," Columbia Law Review 112, no. 1 (2012).
} 
In general, removing the automatic stay exemption would act as a curb on repos by reducing the liquidity of the collateral, particularly in tri-party markets. ${ }^{42}$ This can be viewed as a sensible regulatory measure to reduce the reliance on lower-quality collateral, akin to setting minimum haircuts. However, removing this exemption would probably be unwarranted for higher-quality collateral, such as most government-guaranteed securities. ${ }^{43}$

A rather different proposal comes from Acharya and Öncü who propose creating a special resolution authority called 'Repo Resolution Authority' (RRA) for addressing the potential systemic risks of repo collateral fire sales during a financial crisis. They advocate for removing the bankruptcy safe harbor except for high quality government bonds. In the event of a default by a counterparty on a repo, the RRA would make a liquidity payment to repo lenders and then would try to liquidate the collateral in an orderly manner. In this case, an ex-ante fee should be charged on the repo lenders and there should also be certain eligibility criteria on repo lenders. ${ }^{44}$

In the U.S., as a response to the concerns of run on repo giving rise to disorderly resolution of banks, the exemption from automatic stay no longer entirely applies to banks being taken over by the Federal Deposit Insurance Corporation (FDIC). ${ }^{45}$ Similarly, under the Dodd-Frank Act, counterparties to a "covered financial company' ${ }^{46}$ may not be able to terminate contracts after the institution is put under the FDIC's receivership. ${ }^{47}$ To address the issue of moral hazard, Dodd-Frank Act's section 214 further stipulates that taxpayers' funds cannot be used to

\footnotetext{
${ }^{42}$ Goralnik, "Bankruptcy-Proof Finance and the Supply of Liquidity."

${ }^{43}$ See Nabilou and Pacces, "The Law and Economics of Shadow Banking."

${ }^{44}$ Viral V. Acharya and T. Sabri Öncü, "A Proposal for the Resolution of Systemically Important Assets and Liabilities: The Case Ofthe Repo Market," International Journal of Central Banking 9, no. S1 (2013).

${ }^{45}$ For the operation of FDIC after receivership of the regulated bank, see Duffie and Skeel, "A Dialogue on the Costs and Benefits of Automatic Stays for Derivatives and Repurchase Agreements," 4. see also 12 U.S.C. $\S$ 1821 (e)(9), (10).

${ }^{46}$ Defined in 12 U.S.C. $\$ 5381$ (a)(8) which does not include insured depository institution.

${ }^{47}$ See. 12 U.S.C. $§ 5390$ (b)(13)(C)(i), which provides for a general prohobition to exercise certain contractual rights without consent. See also Duffie/Skeel p. 4 et sqq.
} 
prevent financial companies from liquidation, nor should they bear any losses in the liquidation process led by the authorities. ${ }^{48}$

Under the EU law of financial collateral arrangements, holders of instruments involving financial institutions whereby cash or securities are transferred by way of security financial collateral arrangement (as opposed to title transfer financial collateral arrangement) are protected from the application of the insolvency laws or other measures that could hinder the enforcement of their close-out netting. ${ }^{49}$ As discussed above, since such protections result in the erosion of the financial institutions goodwill, they were viewed as posing major challenges to insolvency procedures and successful resolutions. To address this problem, the FCD was revised by the Bank Recovery and Resolution Directive (BRRD) $)^{50}$ to allow for a stay on closeout netting and enforcement provision for up to 48 hours. ${ }^{51}$ This new 48 -hour rule is intended to afford resolution authorities with adequate time for an orderly resolution. Any modification beyond that has not gained considerable traction. ${ }^{52}$ As of this writing, despite heated discussions and new proposals in the U.S., ${ }^{53}$ there has been no equivalent change in the bankruptcy framework of repos.

\footnotetext{
4812 U.S. Code $\$ 5394$ (a)(c).

${ }^{49}$ Directive 2002/47/EC on Financial Collateral Arrangements [2002] OJ L 168/43, as amended by Directive 2009/44/EC [2009] OJ L146/37. Articles 4 \& 8.

${ }^{50}$ Directive 2014/59/EU of the European Parliament and of the Council of 15 May 2014 establishing a framework for the recovery and resolution of credit institutions and investment firms and amending Council Directive 82/891/EEC, and Directives 2001/24/EC, 2002/47/EC, 2004/25/EC, 2005/56/EC, 2007/36/EC, 2011/35/EU, 2012/30/EU and 2013/36/EU, and Regulations (EU) No 1093/2010 and (EU) No 648/2012, of the European Parliament and of the Council, OJ L 173, 12.6.2014, p. $190-348$.

${ }^{51}$ See, BBRD, arts. 70-71 and 118 that revises the FCD by inserting a new article 1(6) to that directive.

${ }^{52}$ Philipp Paech, "Shadow Banking: Legal Issues of Collateral Assets and Insolvency Law," (Brussels: European Parliament; Directorate General for Internal Policies; Policy Department A: Economics and Scientific Policy, 2013), 5. See, Skeel and Jackson, "Transaction Consistency and the New Finance in Bankruptcy."

"Skeel and Jackson identify five adverse effects that the safe harbors for derivatives and repos have on financial markets: Skeel and Jackson, "Transaction Consistency and the New Finance in Bankruptcy," pp. 166-168." Although Skeel and Jackson argue that the most bankruptcy safe harbor should be eliminated, they argue that there should still be automatic stay safe harbors for repos collateralized by cash like instruments (cash like collateral used in repo transactions.) Skeel and Jackson, pp. 156-157. Other commentators believe that the safe harbors should be removed even for such instruments. See Norbert J. Michel, "Fixing the Regulatory Framework for Derivatives," (Washington, D.C.2016).

${ }^{53}$ For an overview of these proposals, see: Jodie A Kirshner, "The Bankruptcy Safe Harbor in Light of Government Bailouts: Reifying the Significance of Bankruptcy as a Backstop to Financial Risk," NYUJ Legislation and Public Policy 18 (2015).
} 


\section{Reuse of collateral}

One of the most controversial aspects of repo transactions is rehypothecation or reuse of collateral. ${ }^{54}$ Rehypothecation occurs when an intermediary holding securities on behalf of investors grants a security interest or encumbers those securities to obtain financing for itself. ${ }^{55}$ Rehypothecation is often practiced in the relationship between broker-dealers and their clients (risk portfolio managers or cash portfolio managers) and it provides an inexpensive source of financing for financial institutions, especially broker-dealers. ${ }^{56}$ For example, in repo financing, the broker-dealer often hypothecates the collateral provided by the risk portfolio manager (PM) so that it can procure financing for the risk PM from a cash $\mathrm{PM}$ in a matched-book method. ${ }^{57}$ Rehypothecation plays an important role in providing liquidity to markets. However, it is believed to pose risks to financial stability, particularly if one looks at how the GFC manifested itself; namely, as withdrawals of collateral from investment banks such as Lehman Brothers. ${ }^{58}$

One of the objectives of the Dodd-Frank Act in the U.S. is to protect the collateral that clients post with their prime broker-dealers ${ }^{59}$ and to ultimately discourage clients' run on prime brokers. To further such an objective, the collateral posted by clients should not be commingled with the prime broker's funds. Such a protection offered to clients' collateral can

\footnotetext{
54 it appears that the term rehypothecation would be confusing term in English law because its commercial use if different from its legal use. the word reuse could be a better and more precise term than rehypothecation. For more details See Daniel Harris, "Use of Customer Securities by Uk Prime Brokers: The Road Ahead," Law and Financial Markets Review 7, no. 2 (2013). Reuse sometimes is also called repledge. For the difference between rehypothecation and reuse, see: Manmohan Singh, "Velocity of Pledged Collateral: Analysis and Implications," IMF Working Paper WP/11/256 (2011): 9.

${ }^{55}$ Steven L. Schwarcz, "Distorting Legal Principles," Journal of Corporation Law 35, no. 4 (2010): 699.

${ }^{56}$ Christian A. Johnson, "Derivatives and Rehypothecation Failure: It's 3:00 Pm, Do You Know Where Your Collateral Is?," Arizona Law Review 30 (1997): 969.

${ }^{57}$ See: Pozsar, "Shadow Banking: The Money View."

${ }^{58}$ Darrell Duffie, "The Failure Mechanics of Dealer Banks."

Schwarcz, "Distorting Legal Principles," 700. See also: James Aitken and Manmohan Singh, Deleveraging after Lehman-Evidence from Reduced Rehypothecation (Epub), vol. 9 (International Monetary Fund, 2009). (showing that the after Lehman bankruptcy there was a significant reduction in rehypothecation by broker dealers, although this reduced counterparty risks in the system, it comes at the cost of having less liquid markets.) Singh finds that the decline in the source of pledgeable collateral, and the subsequent reduction in the liquidity of the markets, had an effect on the conduct of monetary policy. See: Singh, "Velocity of Pledged Collateral: Analysis and Implications."

${ }^{59}$ Regulation T (12 CFR $\$ 220$ - Code of Federal Regulations, Title 12, Chapter II, Subchapter A, Part 220) in the U.S. prohibits the use of collateral to the amount of $140 \%$ of the collateral, while in the UK, there is no limit on that.
} 
in fact reduce the likelihood of clients' runs on prime brokers. Similar developments have been underway in Europe. In addition to regulatory initiatives, market discipline has already, to a significant extent, reduced the susceptibility of prime brokers to runs by their clients. For example, many hedge funds require prime brokers not to rehypothecate their collateral and keep their cash in separate accounts.

Rehypothecation of collateral is subject to regulation on both sides of the Atlantic. According to section 724 of the Dodd-Frank Act, ${ }^{60}$ parties accepting money, securities or property to margin, guarantee, or secure a swap cleared by a derivatives clearing organization should register as Futures Commission Merchants (FCMs). The FCMs should treat all money, securities, and property of any swaps customer as belonging to the swap customer. They are also required to separately account for and not commingle the customer's funds with the funds of the FCM.

In addition, section 724 requires the segregation of assets for uncleared swaps. According to this requirement, a swap dealer or a Major Swap Participant (MSP) should notify the party wishing to enter a swap transaction at the beginning of the swap transaction that it has "the right to require the segregation of the funds or other property supplied to margin, guarantee, or secure the obligations of the counterparty." The aim of this provision is to prevent the swap dealers or an MSPs from using customers' assets posted with them as collateral to be used as margin, guarantee, or as a security for any of its trades. ${ }^{61}$ As for repos, in the U.S., the amount of a client's assets that can be rehypothecated by a prime broker or a broker dealer is capped to the equivalent of $140 \%$ of the client's liability to the prime broker or dealer, ${ }^{62}$ but such a cap might not be needed under the UK securities financing transactions as discussed below. ${ }^{63}$

\footnotetext{
607 U.S.C. $\S 6 \mathrm{~d}$

${ }^{61}$ Lloyd, Clancy and Kumar, Hedge Funds and Systemic Risk, pp. 77-79

${ }^{62}$ Federal Reserve Regulation T (12 CFR §220) and SEC Rule 15c3-3

${ }^{63}$ Manmohan Singh and James Aitken, "The (Sizable) Role of Rehypothecation in the Shadow Banking System," IMF Working Paper 10/172 (2010).
} 
Financial collateral arrangements in Europe is mainly governed by the FCD. ${ }^{64}$ The main aim of the FCD is to harmonize the regime applicable to financial collateral arrangements. The FCD governs the collateral provided using title transfer or the grant of a security interest. ${ }^{65}$ The main provisions include the prohibition of the recharacterization of title transfer as grant of security interests, ${ }^{66}$ right of use for collateral taker, ${ }^{67}$ a mechanism for rapid enforcements including close-out netting, ${ }^{68}$ and protections in insolvency (bankruptcy safe harbor). ${ }^{69}$ The FCD generally strengthens the position of collateral takers vis-à-vis collateral providers and creditors. $^{70}$

In addition, at the EU level, on 23 December 2015, the European regulation on transparency of securities financing transactions and of reuse (SFTR) was published. ${ }^{71}$ This regulation contains measures aimed at increasing the transparency of the securities lending and repurchase agreements by mandating firms to report all such transactions to trade repositories. The SFTR is mainly concerned with the transparency of the SFTs, and reuse. Since transparency helps increase market discipline and the effectiveness of the supervision, the SFTR strives to enhance the transparency of the SFTs through the following three mechanisms:

1. Reporting the transactions to a central database, except where one of the parties to the transaction is a central bank, which could help the supervisor better identify the interconnectedness of banks and shadow banks.

\footnotetext{
${ }^{64}$ Directive 2002/47/EC on financial collateral arrangements [2002] OJ L168/43, as amended by Directive 2009/44/EC [2009] OJ L146/37 and Directive 2014/59/EU [2014] OJ L173/190.

In addition, Chapter V of the UNIDROIT Convention on Substantive Rules for Intermediated Securities (Geneva Securities Convention or GSC) has also provisions governing financial collateral arrangements and reuse. However, this convention is far from being signed and adopted in the near future. See UNIDROIT Convention on Substantive Rules for Intermediated Securities <http://www.unidroit.org/english/conventions/2009intermediatedsecurities/convention.pdf> accessed 31 May 2014. It was adopted in 2009.

${ }^{65}$ For the distinction between the title transfer financial collateral arrangement and security financial collateral arrangement, see: Directive 2002/47/EC, Art 2(1)(a), (b) and (c).

${ }^{66}$ Directive 2002/47/EC Art. 6

${ }^{67}$ Directive 2002/47/EC, Art. 5

${ }^{68}$ Directive 2002/47/EC, Arts. 4 and 7

${ }^{69}$ Directive 2002/47/EC, Art 8.

${ }^{70}$ Such a provision is based on the ground that providing such a special treatment would improve market liquidity, lead to inexpensive credit and contribute to financial stability by preventing domino effects originating from individual insolvencies.

${ }^{71}$ Regulation (EU) 2015/2365 of the European Parliament and of the Council of 25 November 2015 on transparency of securities financing transactions and of reuse and amending Regulation (EU) No 648/2012 (Text with EEA relevance)
} 
2. Higher levels of transparency on the practices of investment funds engaged in the SFTs and total return swaps by imposing reporting requirements on those operations.

3. Higher levels of transparency of the reuse of collateral by imposing minimum conditions to be met for reuse, such as written agreement and prior consent. ${ }^{72}$

Therefore, the SFTR requires prior consent for reuse of collateral, and disclosure of risks and consequences of reuses to the parties posting the collateral. In other words, the SFTR subjects the right to reuse of collateral to the notice and consent requirements. ${ }^{73}$ Namely, the receiving counterparty should inform the counterparty providing the collateral in writing of the risks involved in consent to a right of reuses of collateral ${ }^{74}$ and in concluding a title transfer collateral arrangement, and the providing counterparty should grant its express consent to reuse.

One of the significant differences in the regulatory treatment of SFTs across the Atlantic is the limit or cap on the rehypothecation of collateral in the U.S. as opposed to, many other markets including the EU markets. At the EU level, there is no cap on the reuse, as opposed to the $140 \%$ cap in the U.S. ${ }^{75}$ However, individual member states, such as France, have established similar limitations (140\% cap). Although in the UK there is no $140 \%$ cap on rehypothecation, it seems that the percentage used in the U.S. has created anchoring effect, and in fact many hedge funds are using $140 \%$ cap as a benchmark in negotiating prime brokerage agreements with their banks. ${ }^{76}$

\section{The composition, structure and organization of repo markets}

\section{Participants}

The main participants in repo transactions are different across the Atlantic. In Europe, repo is widely used by securities market intermediaries and leveraged investors such as hedge funds

\footnotetext{
${ }^{72}$ FAQs on SFTR

${ }^{73}$ Article 15 of the SFTR

${ }^{74}$ Art. 5 of Directive 2002/47/EC

${ }^{75}$ Autorité des Marchés Financiers (AMF), "The Reuse of Assets: Regulatory and Economic Issues," (November 9, 2016).

${ }^{76}$ Singh and Aitken, "The (Sizable) Role of Rehypothecation in the Shadow Banking System," 12.
} 
seeking cheap funding. ${ }^{77}$ Their common counterparties are usually commercial banks, central banks and other risk-averse investors looking for relatively safe investment opportunities. ${ }^{78}$ Many banks with high levels of expertise therefore appear on both sides of different repo transactions. Therefore, a big interbank repo market, which has access to ECB's liquidity, is at the center of European repo market (See Figure below). ${ }^{79}$

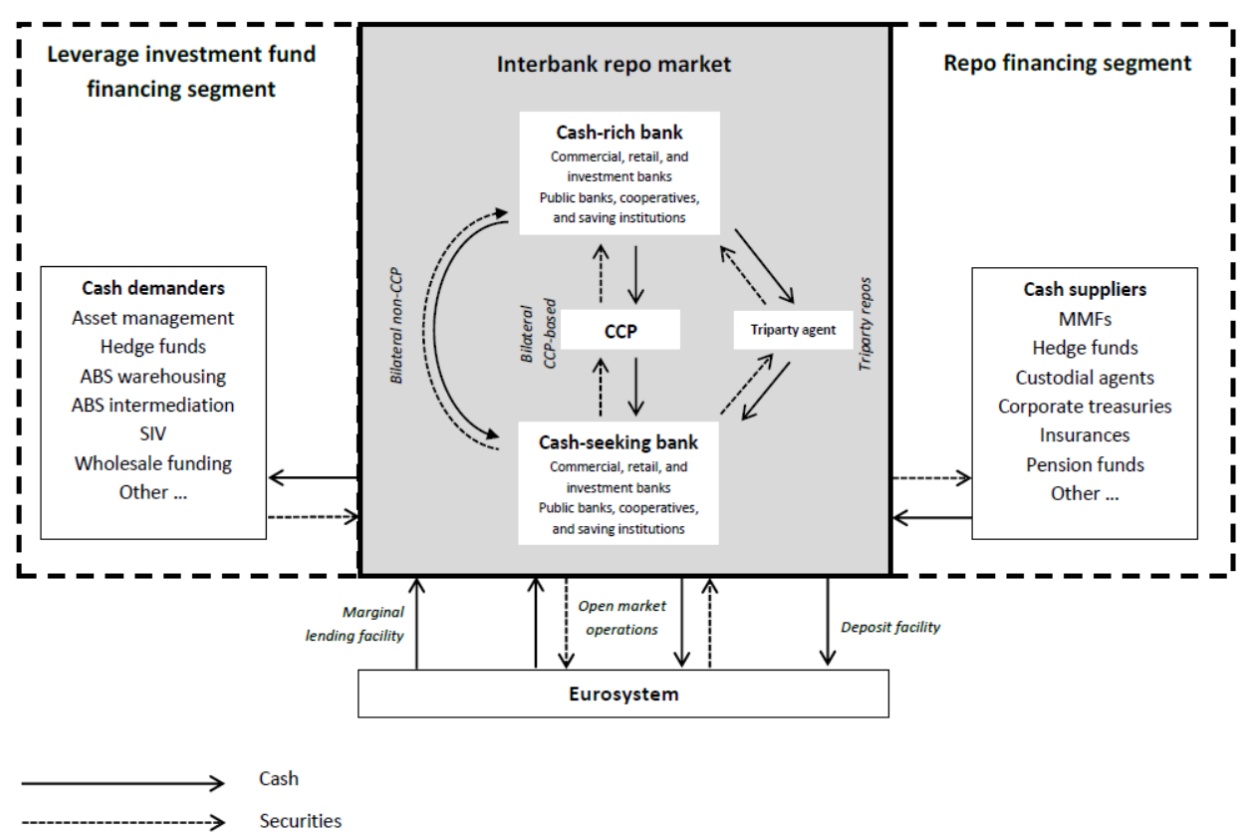

In the U.S., at least one party involved in a repo transaction is almost always a securities dealer. Those securities dealers may wish to finance their securities inventory or lend cash to their clients upon request. Other investors include Money Market Funds (MMFs), asset managers and others who are looking for specific securities to hedge or profit from speculation by borrowing securities from the dealers. ${ }^{80}$ Those various market participants all depend on a well-functioning interdealer repo market. (See Figure below, Source: OFR analysis ${ }^{81}$ )

\footnotetext{
${ }^{77}$ Association, "Frequently Asked Questions on Repo," 8.

78 Ibid.

${ }^{79}$ Loriano Mancini, Angelo Ranaldo, and Jan Wrampelmeyer, "The Euro Interbank Repo Market," The Review of Financial Studies 29, no. 7 (2016): 1753. Figure on p. 1752.

${ }^{80}$ Copeland et al., "Key Mechanics of the Us Tri-Party Repo Market," 2.

${ }^{81}$ Viktoria Baklanova, Ocean Dalton, and Stathis Tompaidis, "Benefits and Risks of Central Clearing in the Repo Market," Office of Financial Research Brief Series 17, no. 04 (2017): 2.
} 


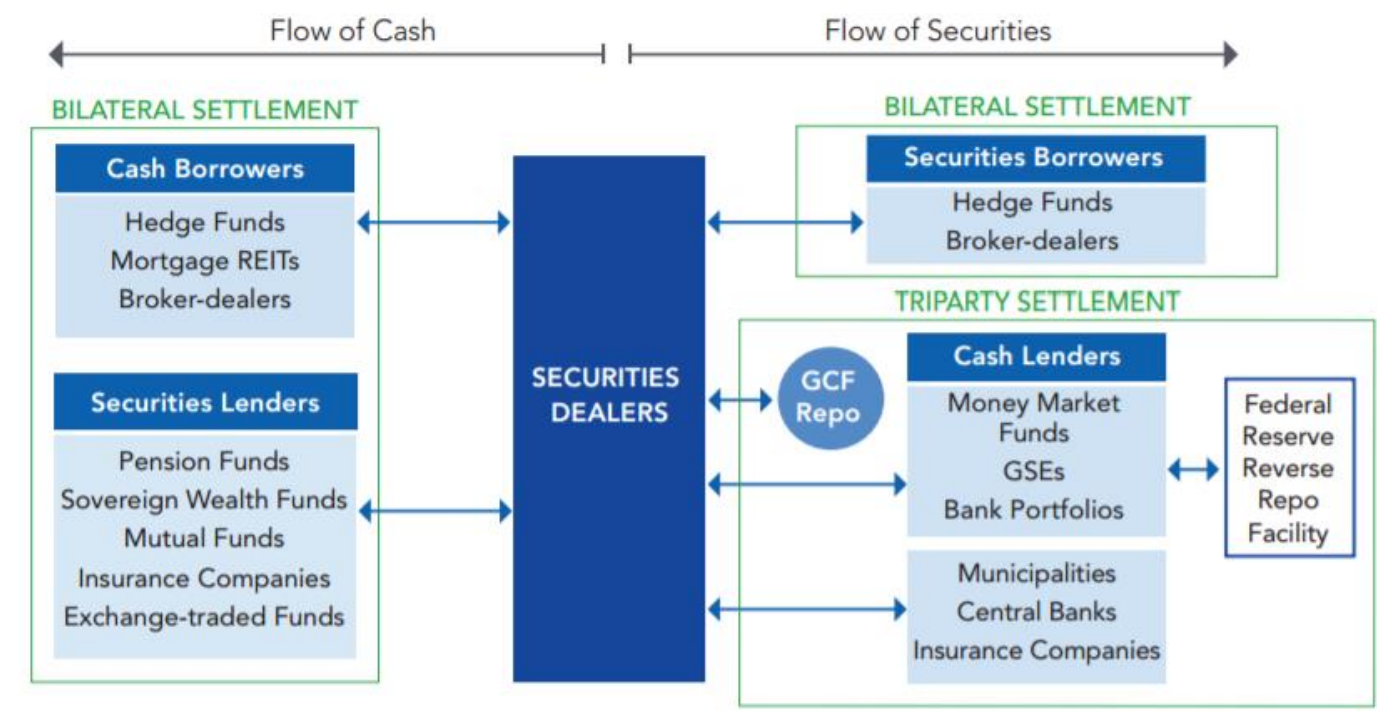

Note: REITs are Real Estate Investment Trusts, GSEs are Government-Sponsored Enterprises, and GCF is General Collateral Financing Repo Service.

\section{Maturity}

Traditionally, the repo transactions in the U.S. have a shorter maturity than those in Europe. ${ }^{82}$ The following figure shows that both before and after the GFC, over 90 percent of the notional value of repos are overnight.

${ }^{82}$ Krishnamurthy, Nagel, and Orlov, "Sizing up Repo," 29-30. 
(b) Weighted by notional value

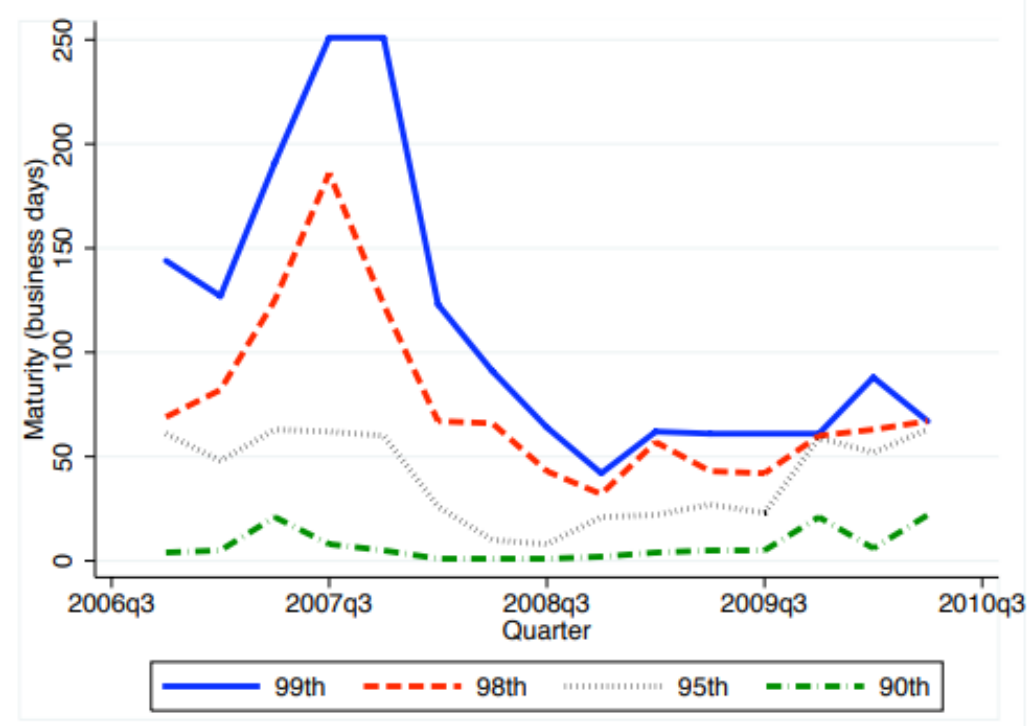

Figure 5: Percentiles of Repo Maturities

In contrast, according to the latest data by ICMA (December 2017), only $16.9 \%$ of repos traded in Europe have an overnight maturity. ${ }^{83}$ It appears that the level of overnight repos has had a declining trend in Europe. In ICMA's June 2017 survey, 18.4\% of the European repos had an overnight maturity. ${ }^{84}$

\footnotetext{
${ }^{83}$ International Capital Market Association (ICMA), "European Repo Market Survey: Number 34- Conducted December 2017," (March 2018): 19.

84 "European Repo Market Survey: Number 33 - Conducted June 2017," (October 2017): 19.
} 


\section{Maturity analysis (Q1.7)}

Table 2.14 - Maturity analysis

\begin{tabular}{|l|c|c|c|}
\cline { 2 - 4 } \multicolumn{1}{c|}{} & December 2017 & June 2017 & December 2016 \\
\hline open & $7.8 \%$ & $6.6 \%$ & $6.4 \%$ \\
\hline $\mathbf{1}$ day & $16.9 \%$ & $18.4 \%$ & $18.9 \%$ \\
\hline 2 days to 1 week & $22.6 \%$ & $22.3 \%$ & $21.2 \%$ \\
\hline $\mathbf{1}$ week to 1 month & $15.9 \%$ & $20.0 \%$ & $16.1 \%$ \\
\hline $\mathbf{> 1}$ month to 3 months & $16.3 \%$ & $12.6 \%$ & $18.9 \%$ \\
\hline $\mathbf{> 3}$ months to $\mathbf{6}$ months & $\mathbf{4 . 4 \%}$ & $4.9 \%$ & $4.3 \%$ \\
\hline $\mathbf{> 6}$ months to $\mathbf{1 2}$ months & $\mathbf{2 . 5 \%}$ & $3.2 \%$ & $2.5 \%$ \\
\hline $\mathbf{> 1 2}$ months & $1.5 \%$ & $1.5 \%$ & $1.3 \%$ \\
\hline forward-start & $12.2 \%$ & $10.5 \%$ & $10.5 \%$ \\
\hline
\end{tabular}

Figure 2.14 - Maturity analysis (main survey)

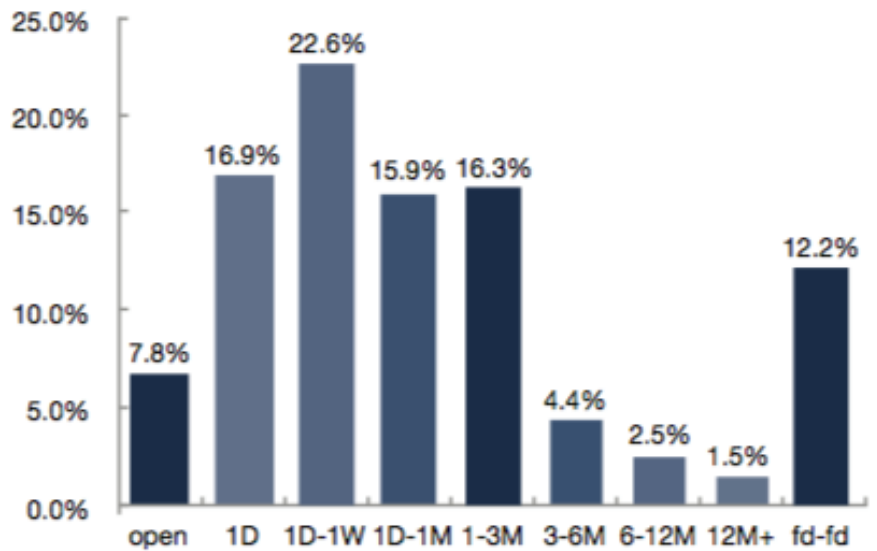

Overnight repos could serve as an alternative funding source of bank deposits. ${ }^{85}$ Overnight or shorter-term repo financing means higher maturity transformation if the short-term repos are used to finance long-term loans. This means that the maturity transformation happening through repo transactions in the U.S. is much more excessive than in the EU. Therefore, ceteris paribus, financing by short-term repos can be more prone to runs compared to longer-term repos. Accordingly, in terms of maturity, the U.S. repo markets are more prone to runs and are overall riskier than the EU repo markets. ${ }^{86}$

\footnotetext{
${ }^{85}$ Copeland et al., "Key Mechanics of the Us Tri-Party Repo Market," 3.

${ }^{86}$ The longer-term nature of repo markets in the EU might explain why repo constitute a higher proportion of the balance sheet of key market intermediaries in the EU. See; Association, "Frequently Asked Questions on Repo.", question no. 7.
} 
Where the market is dominated by overnight repos, the initial margin or haircut play a more important role in valuing the collateral. With the underlying collateral returned to the investor the next business day, parties would likely assume the likelihood of the fluctuation of the collateral value to be minimal. Moreover, lacking the possibility of a margin call, the collateral delivered should be negotiated to reflect the market value more precisely in the event of a default. This might help explain why an increase of repo haircuts can be observed in the U.S. during the GFC. ${ }^{87}$

\section{Difference in the composition of collateral}

Another important difference between the U.S. and the EU repo markets concerns the composition of the collateral used in the repo markets. It is estimated that around $80 \%$ of the collateral used in the European repo markets is government securities. Structured securities used as collateral in the EU markets are a small component of the overall collateral backing repo transactions, and where they are used, they are often used in tri-party repo markets. However, tri-party repos amount to $10 \%$ of the European repo markets, and the use of structured securities as collateral amount to about $10 \%$ of the European tri-party repos. ${ }^{88}$

Given that one of the reasons for the predominance of the repo transactions is the supply of highly-demanded safe assets, ${ }^{89}$ the use of government securities as collateral in the EU repo markets is of special importance for the financial stability, because these securities have

\footnotetext{
${ }^{87}$ Krishnamurthy, Nagel, and Orlov, "Sizing up Repo.", 32.

${ }^{88}$ ICMA FAQs. How is it changing?

In Europe, the repo market is now shrinking — its base size was estimated to be $€ 5.4$ tn in June, down $1.6 \%$ on the previous year, according to the International Capital Markets Association.

https://www.ft.com/content/7b413b0c-960f-11e6-a80e-bcd69f323a8b

${ }^{89}$ For the concept of safe assets, see International Monetary Fund, "Global Financial Stability Report: The Quest for Lasting Stability," (Washington, DC: International Monetary Fund, April 2012), 81-122. See also, Anna Gelpern and Erik F. Gerding, "Rethinking the Law In "Safe Assets"," in Reconceptualising Global Finance and Its Regulation, ed. Ross P. Buckley, Emilios Avgouleas, and Douglas W. Arner (New York: Cambridge University Press, 2016).

Safe assets are described as "a variety of financial claims on public of private sector entities that are used as if they were riskfree." See Gelpern and Gerding, "Rethinking the Law In "Safe Assets"," 159. See also: Fund, "Global Financial Stability Report: The Quest for Lasting Stability," 88-105. Gorton et al. describe safe assets as "information-insensitive" or "immune to adverse selection in trading because agents have no desire to acquire private information about the current health of the issuer". See Gary Gorton, Stefan Lewellen, and Andrew Metrick, "The Safe-Asset Share," The American Economic Review 102, no. 3 (2012): 101.
} 
proven to be resilient to runs in the times of crises. As the study by Gorton and Metrick on runs on repos backed by Asset-Backed Commercial Paper (ABCP) shows, during the financial crisis, the major repo runs occurred on the commercial paper (ABCP) used as collateral. ${ }^{90}$ Other studies show that such a run did not occur on repos backed by government bonds. ${ }^{91}$ Therefore, in the absence of sovereign default risk, the risk of a run on the European repo markets cannot be deemed significant. As the financial crisis also showed, the EU repo markets weathered the crisis much better than the US markets did, perhaps because of the reliance of the EU markets on repos collateralized by government bonds.

\section{Differences in market infrastructure}

\section{CCP clearing}

Central Clearing Counterparties (CCPs) play an important role in the well-functioning of the financial markets. A CCP is a legal person interposing itself between the counterparties to a trade, becoming the buyer to every seller and the seller to every buyer. ${ }^{92}$ 'Clearing' refers to the processes and activities carried out between trade and settlement. It concerns establishing positions such as calculation of net obligations, and ensuring the availability of financial instruments, cash, or both to secure the exposures arising from those positions. ${ }^{93}$ For example, a derivative contract is cleared if the performance of the buyer and the seller is guaranteed by a CCP. Normally, the lender and the borrower in a repo will each enter into a clearing agreement with their custodian bank. In a bilateral repo, this custodian bank is also responsible for clearing and settling the securities on behalf of each party. ${ }^{94}$

\footnotetext{
${ }^{90}$ (Gorton \& Metrick focus on the commercial paper as the collateral used in the U.S. markets, which makes their study irrelevant for EU financial markets.); Gorton and Metrick, "Securitized Banking and the Run on Repo."; "Regulating the Shadow Banking System." Shleifer and Krishnamurty suggest that the run only occurred on the repos with ABCP collateral, and not repos backed by government collateral. See Andrei Shleifer, "Comments and Discussions (Regulating the Shadow Banking System by Gary Gorton \& Andrew Metrick)," Brookings Papers on Economic Activity (2010).; Krishnamurthy, Nagel, and Orlov, "Sizing up Repo."

${ }^{91}$ Shleifer, Krishnamurthy.

92 Art. 2(1), Regulation (EU) No 648/2012 of the European Parliament and of the Council of 4 July 2012 on OTC derivatives, central counterparties and trade repositories, OJ L 201, 27.7.2012. (EMIR Regulation)

${ }^{93}$ EMIR, Art. 2(3)

${ }^{94}$ Baklanova, Copeland, and McCaughrin, "Reference Guide to Us Repo and Securities Lending Markets," 5.
} 
A major difference between the EU and the U.S. repo markets is that a larger portion of repos in the EU is centrally cleared ${ }^{95} \mathrm{CCPs}$ contribute to one of the most important self-stabilizing mechanisms in repo markets. By becoming a prime party to every seller and buyer, a CCP apply more rigorous risk management methods in a larger scale and can reduce risk exposures in total through multilateral netting, leading to overall smaller balance sheets. Even if a party is in default, the CCPs will continue paying their counterparty their variation margin payments by selling some of the initial margin of the collateral provided by the defaulting party. A reduced size of collateral substantially mitigates the risk of fire-sales. The CCP is also in a better position to reallocate the collateral without selling it in the market, avoiding a forced liquidation. ${ }^{96}$ It is also more efficient for regulators to observe the financial markets in total, because it would be easier to impose a reporting duty from those who have access to firsthand transaction data. The market transparency can also be improved through central clearing. ${ }^{97}$

Nowadays, the principal business model in European CCP-based interbank repo market is for the parties to negotiate a repo via electronic repo-trading system. The major clearing houses in Europe include LCH-Clearnet, Eurex Clearing, CC\&G and MEFF. ${ }^{98}$ Alternatively, bilateral repos directly negotiated via voice-brokers can also register the transaction with a CCP posttrade. ${ }^{99}$ The transactions between members of a CCP could be thus cleared multilaterally even if the repo transaction itself remains bilateral.

Yet there are also some concerns to the wider use of CCPs. ${ }^{100}$ Currently, CCPs usually only accept high-quality, highly liquid collateral (e.g., government bonds) which constitutes the bulk of collateral in repo transactions. This could, however, exacerbate the problem of

\footnotetext{
${ }^{95}$ Association, "Frequently Asked Questions on Repo," 25.

${ }^{96}$ Baklanova, Dalton, and Tompaidis, "Benefits and Risks of Central Clearing in the Repo Market," 3.

${ }^{97}$ Also Ibid., 7. See also: Peter Norman, The Risk Controllers: Central Counterparty Clearing in Globalised Financial Markets (Chichester, West Sussex: John Wiley \& Sons, Ltd., 2011).

98 Association, "Frequently Asked Questions on Repo," 25.

99 Ibid.

${ }^{100}$ See Ibid., p. 24.
} 
collateral shortage. The CCPs will likely need higher margining and contribution from clearing members, they also would set higher haircuts to improve their resilience to possible defaults, ${ }^{101}$ resulting in a decrease in overall market efficiency. Moreover, as Duffie and Zhu point out, since introducing a CCP means a loss in bilateral netting opportunities in other classes of derivatives between the parties, the regulator should always consider whether the benefits of multilateral netting could outweigh that loss. ${ }^{102}$ In addition, it is important to note that by using CCPs, the liquidity risks will not simply disappear, they are rather shifted and concentrated within the CCPs, the failure of which would be even more devastating to the financial system.

To decrease the likelihood of a member's default, CCPs often set certain membership criteria before they accept a financial institution as their clearing member. ${ }^{103}$ CCPs also demand variation margins from their members on an intraday basis to maintain an appropriate risk buffer against market volatility. In the event of default by a clearing member, the conservatively calculated initial margin could be used in the close-out process before the default fund of the defaulting member is disposed. The default funds of non-defaulting members come only in play when the CCP's contribution is exhausted. The CCPs often have recovery tools to replenish the default funds, they also have a "default waterfall" for their own protection. For example, in Europe in covering losses, a CCP should use the following default waterfall.

1. Margin posted by a defaulting clearing member;

2. The default fund contribution of the defaulting clearing member;

3. Dedicated own recourses (CCP's skin in the game); and

\footnotetext{
${ }^{101}$ Baklanova, Dalton, and Tompaidis, "Benefits and Risks of Central Clearing in the Repo Market," 3.

${ }^{102}$ Darrell Duffie and Haoxiang Zhu, "Does a Central Clearing Counterparty Reduce Counterparty Risk?," The Review of Asset Pricing Studies 1, no. 1 (2011): 2..

${ }^{103}$ See for example: Eurex Clearing AG, "How to Get Started on Eurex Repo: Eurex Clearing Guidelinie," (6 November 2017), 7.
} 
4. Default fund contributions of the non-defaulting clearing members and any other financial resources of the $\mathrm{CCP} .{ }^{104}$

There has been concerns about the waterfall design itself giving the non-defaulting clearing members a false sense of security, as they rely on the CCP and its default funds as a last resort. ${ }^{105}$

European Market Infrastructure Regulation (EMIR) ${ }^{106}$ contains several articles that are crucial to the operation of a CCP in Europe. Article 45 EMIR stipulate that in a default situation, the contributions of non-defaulting party can only be used if both the contributions of defaulting member and the dedicated own resources of the CCP has been exhausted. The margin of a non-defaulting member can never be used to cover the losses incurred from the default of another clearing member. ${ }^{107}$ The amount of own resources that the CCP must dedicate is known as 'skin in the game' clause which aligns the interest of clearing members and the CCP shareholders and managers. This amount is set at $25 \%$ by the technical standards which shall be revised on an annual basis. ${ }^{108}$

EMIR requires certain derivatives (standardized OTC derivatives) to be cleared through CCPs. Similar requirements are in place in the U.S. pursuant to the Dodd-Frank Act. Title VII of the Act ${ }^{109}$ and CFTC Regulations set forth requirements for the registration of Derivatives Clearing Organizations (DCOs), effective June 2016. However, as of this writing, despite

\footnotetext{
${ }^{104}$ Art. 45 EMIR

${ }^{105}$ See Bora Yagiz, "Clearinghouses' Default "Waterfall” Offers No Panacea against Their Potential Failure," Regulatory Intelligence: Thomson Reuters (2014).

${ }^{106}$ Regulation (EU) No 648/2012 of the European Parliament and of the Council of 4 July 2012 on OTC derivatives, central counterparties and trade repositories, OJ L 201, 27.7.2012.

${ }^{107}$ Art. 45 (4) EMIR

${ }^{108}$ Art. 35 (2). Commission Delegated Regulation (EU) No 153/2013 of 19 December 2012 supplementing Regulation (EU) No 648/2012 of the European Parliament and of the Council with regard to regulatory technical standards on requirements for central counterparties, OJ L 52, 23.2.2013, p. 41-74;

1097 U.S.C. $\S 7 \mathrm{a}-1$
} 
policy proposals for encouraging central clearing of repos, ${ }^{110}$ there is no mandatory central clearing requirement for SFTs in the EU and the U.S.

More recent studies advocate the expansion of usage of CCPs in the U.S. interdealer market. Based on an analysis conducted by the Office of Financial Research (OFR), extending U.S. Treasuries repo CCP services to non-dealers could reduce $81 \%$ of risk exposures, which is substantially higher than the risk reduction that would have been achieved by sole bilateral netting $(63 \%){ }^{111}$

Traditionally, CCPs play a significantly more important role in Europe than in the U.S. Currently, about $70 \%$ of European repo market turnover is being cleared through CCPs. ${ }^{12}$ In the U.S., interdealer government securities transactions were being cleared by the Fixed Income Clearing Corporation (FICC) in General Collateral Finance (GCF) Repo service. However, the GCF Repo market only constituted a very small part of the dealer repo markets. ${ }^{113}$ In addition, since July 2016, the GCF interbank repo service was suspended due to the failure in the implementation of an interactive message system. ${ }^{114}$ This would have reduced the intraday credit they needed from two clearing banks in the U.S. (namely, the Bank of New York Mellon and JP Morgan Chase) and their reliance on the morning unwind on a daily basis. Since the clearing banks would not be extending credit to FICC at no charge and on an uncapped and uncommitted basis ${ }^{115}$ in response to a tri-party reform effort, the FICC

\footnotetext{
${ }^{110}$ See for example: Paolo Saguato, "The Liquidity Dilemma and the Repo Market: A Two-Step Policy Option to Address the Regulatory Void," Stan. JL Bus. \& Fin. 22 (2017).

${ }^{111}$ OFR Analysis, p. 7.

${ }^{112}$ Association, "Frequently Asked Questions on Repo," 25.

${ }^{113}$ Baklanova, Dalton, and Tompaidis, "Benefits and Risks of Central Clearing in the Repo Market," 2.

${ }^{114}$ See Important Notice to FICC:

http://www.dtcc.com/ /media/Files/pdf/2015/11/2/GSD\%20Important\%20Notice\%20GOV088-

15\%20-\%20Suspension\%20of\%20Interbank\%20GCF.pdf last visit: $5^{\text {th }}$ Feb. 2018.

${ }^{115}$ See: SEC (Release No. 34-78206; File No. SR-FICC-2016-002) https://www.sec.gov/rules/sro/ficc/2016/3478206.pdf last visit: $5^{\text {th }}$ Feb. 2018.
} 
can no longer operate its interbank repo service. We will briefly discuss the tri-party repo reform at the end of next subsection.

\section{Collateral management: tri-party repo agents}

A substantial part of the repo transactions in the U.S. is tri-party repos (with overnight maturity), whereas the vast majority of repos in Europe remains bilateral. ${ }^{116}$ In June 2014, the outstanding value of tri-party repo represented more than $60 \%$ of the overall market. At the same time in Europe, this number was merely $10 \% .{ }^{117}$ In a bilateral repo, the lender and the borrower will each enter into a clearing agreement with their custodian bank. In a bilateral repo, this custodian bank is also responsible for clearing and settling the securities on behalf of each party. ${ }^{118}$

In a triparty repo market, a third party (a clearing bank) facilitates the repo settlement, whereas a bilateral repo is directly settled between the two parties to the transactions (collateral and cash provider) without the interposition of a third party. ${ }^{119}$ In a tri-party repo, where primarily General Collateral repos (GC Repos) ${ }^{120}$ are traded, the parties agree on the cash amount first after which they select an eligible security or a basket of securities as collateral, whereas in a special repo, the parties will stipulate the securities at hand first. Comotto defines tri-party repo as "a repo for which collateral management is delegated by the counterparties to a third

\footnotetext{
116 The maturity of the majority of triparty repos is overnight. See Copeland et al., "Key Mechanics of the Us Tri-Party Repo Market," 21. Most of those repos in the U.S. are open (subject to rollover). See Acharya and Öncü, "A Proposal for the Resolution of Systemically Important Assets and Liabilities: The Case Ofthe Repo Market," 310.

${ }^{117}$ Richard Comotto, "A Primer on Tri-Party Repo," (2017). Subtitle 4; Association, "Frequently Asked Questions on Repo.", How is it changing?

In Europe, the repo market is now shrinking - its base size was estimated to be €5.4tn in June, down 1.6 per cent on the previous year, according to the International Capital Markets Association.

https://www.ft.com/content/7b413b0c-960f-11e6-a80e-bcd69f323a8b
}

There are also additional fundamental differences between the U.S and EU triparty repo markets. See "Frequently Asked Questions on Repo.", question no. 24.

${ }^{118}$ Baklanova, Copeland, and McCaughrin, "Reference Guide to Us Repo and Securities Lending Markets," 5.

${ }^{119}$ Copeland et al., "Key Mechanics of the Us Tri-Party Repo Market."

${ }^{120}$ Ibid., 4. 
party agent". ${ }^{121}$ According to him, it is the participation of this said tri-party agent in this one particular stage in the life of a repo that makes it different from a bilateral repo. A tri-party agent is therefore not a CCP, who is interposed into each repo transaction to become a highquality counterparty to buyers and sellers.

In the U.S. there are only two major clearing banks who offer to settle repo transactions on their own balance sheet, namely the Bank of New York Mellon and JP Morgan Chase. ${ }^{122}$ To employ the service of a tri-party agent, the counterparties to the repo will normally enter into a custodian undertaking agreement (CUA) with at least one of these two clearing banks. By entering into such an agreement, the investor also specifies under which rules the accepted collateral should be selected.

The following figure ${ }^{123}$ shows that over $80 \%$ of the collateral used in tri-party repos are Fedwire-eligible collateral backed by governmental agencies.

\footnotetext{
${ }^{121}$ Comotto, "A Primer on Tri-Party Repo.", Subtitle 1.

${ }^{122}$ Baklanova, Copeland, and McCaughrin, "Reference Guide to Us Repo and Securities Lending Markets," 5.

${ }^{123}$ Source: Federal reserve bank of new york, URL: https://www.newyorkfed.org/data-and-statistics/datavisualization/tri-party-repo\#interactive/volume/share_of_total last visit: $5^{\text {th }}$ Feb. 2018.
} 


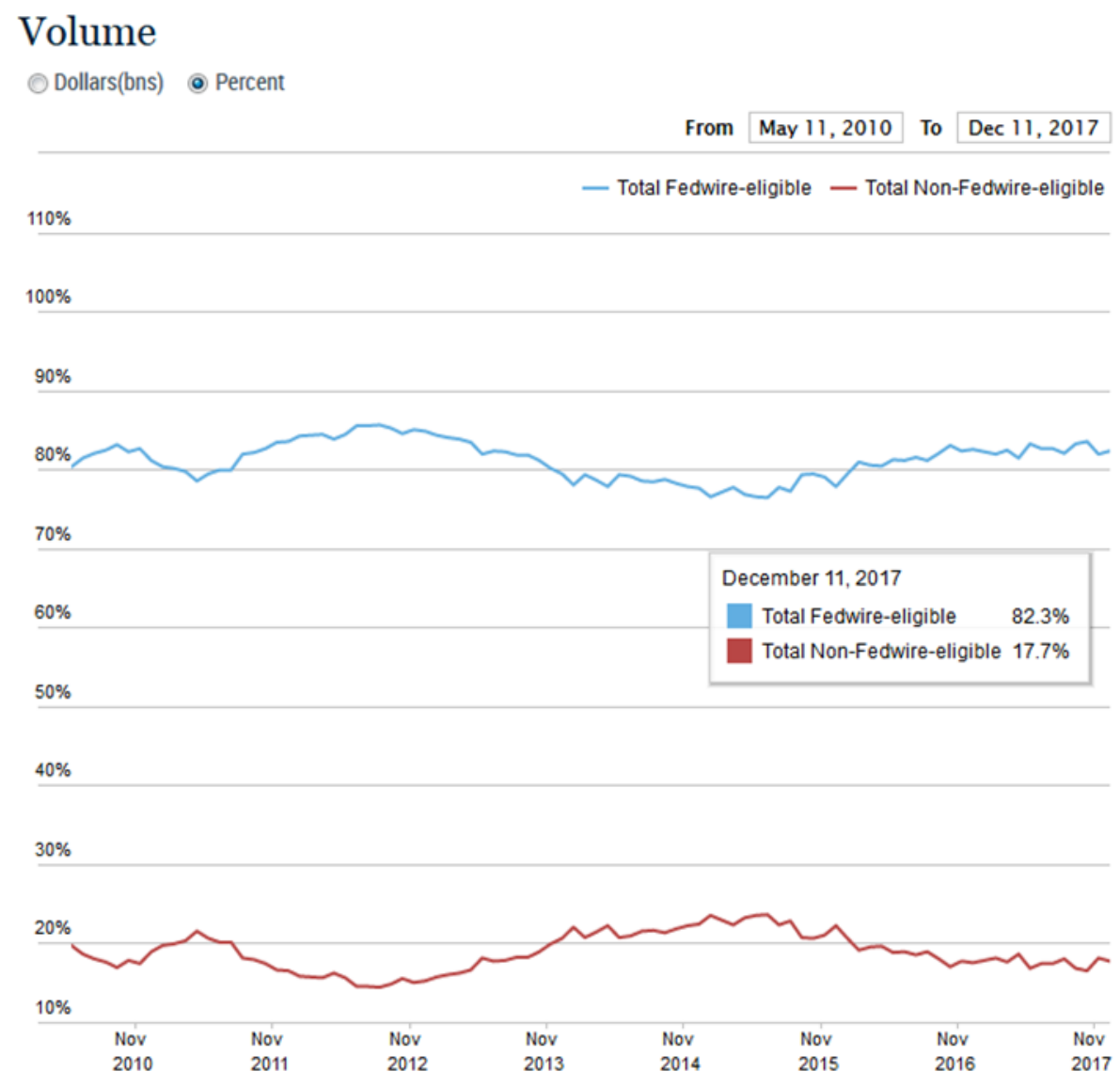

The transition from bilateral into tri-party repo in the U.S. is driven by the urge to alleviate the burden of collateral management on counterparties. ${ }^{124}$ To manage a collateral in a bilateral repo, one must regularly revalue the collateral, call agreed margin from or make supplemental delivery to the other party, respond to the occurrence of income payments and corporate actions, and to valid requests for collateral substitution. ${ }^{125}$ All of the above activities require a significantly high level of expertise which the lender might not have at its disposal. The first solution to this problem was to develop a 'hold-in-custody' repo model where the collateral remains at the seller side, which created the 'double-dipping' problem. To avoid that problem, the parties agree to let a third party to step in, so the seller cannot sell the same security to

\footnotetext{
${ }^{124}$ Comotto, "A Primer on Tri-Party Repo.", Subtitle 2, "How collateral can be re-used by buyers and subsituted by sellers".

${ }^{125}$ Ibid., 41. fn. 15.
} 
different parties without notifying the buyer. A typical tri-party repo transaction in the U.S. has broker-dealers on the borrower side and risk-averse investors such as money market mutual funds on the lender side. ${ }^{126}$

\section{The unwind and rewind process}

The scale of operation of tri-party agents in Europe is much wider and much more expensive than their counterparts in the U.S. ${ }^{127}$ There are also some distinctions as to the concrete activities that a tri-party agent normally conducts in Europe from those conducted by the U.S. tri-party agents. Instead of offering the possibility to adjust margining, collect income payments and make corresponding manufactured payments to the seller or substitute collateral, ${ }^{128}$ the two clearing banks in the U.S. choose to unwind and reallocate the repo on a daily basis. This gives the seller the opportunity to collect any income payments by themselves, revalue the collateral and apply new margining at the latest prices. During this time, the clearing bank provides the borrower with an intraday loan secured by the same security the borrower keeps at the clearing bank. In the meantime, the lender has an unsecured exposure to the clearing bank. In other words, the clearing bank becomes de facto principal to the trade instead of agents. Thus, the clearing banks were providing massive uncommitted loans to dealers without submitting themselves to capital charges.

The process of allocation of securities could take much longer than necessary. The main reason for this phenomenon is the fact that the allocation system used by clearing banks may not be able to meet all the requirements on collateral a cash provider may have. ${ }^{129}$ Although the allocation algorithms used by the clearing banks are being improved over time, it is still difficult to automatically distinguish similar securities. In fact, the dealer often chooses to

\footnotetext{
${ }^{126}$ Ibid., subtitle 4

${ }^{127}$ Ibid., Subtitle 1 and Subtitle 4.

${ }^{128}$ Ibid. Subtitle 1, "What is the function of a tri-party agent".

${ }^{129}$ Comotto, "A Primer on Tri-Party Repo," 10.
} 
manually intervene in this process by specifying exactly which types of securities they wish to include in their collateral pool. Moreover, due to technical reasons in the market infrastructure, many securities cannot be completely settled until late in the afternoon, which prolonged the allocation process further. ${ }^{130}$

To sum up, there was a significant time gap between the daily morning unwind and the completion of allocation process in the traditional U.S. tri-party repo market, which contributes to the fragility of this market. During the crisis, the two clearing banks have served as intraday creditors for as long as 10 hours on a daily basis. ${ }^{131}$ Therefore, in case a dealer experiences distress during this period, if the clearing bank discovers that its loan to the dealer is undercollateralized (maybe due to a crisis situation), the bank will have a huge incentive to sell those assets as quickly as possible in order to keep its leverage ratio in check. Those large amount of 'fire sales' could reduce the value of that collateral, creating a vicious cycle. ${ }^{132}$ The clearing bank may - in contrast to a common pre-crisis false presumption that it could not ${ }^{133}$ refuse to unwind certain securities due to concerns about the dealer to protect itself, leaving the lender exposed to the borrower holding its collateral. ${ }^{134}$ However, this action will certainly have a devastating effect on the dealer, because it will not be able to make delivery of all the securities he uses as collateral. Meanwhile, subject to legal restrictions, some investors might not be legally permitted to hold certain assets on their balance sheets, which forces them to fire-sell the securities, driving the price thereof to the ground.

Due to this flawed design in the key mechanics of the tri-party repo market, at the first sign of distress of a borrower, the collateral acts like a 'hot potato', giving the cash provider a perverse incentive to run on repo with their cash even if the collateral still meets its standards set by the CUA at the moment. In addition, the clearing bank will have an incentive to refuse the

\footnotetext{
${ }^{130}$ Baklanova, Copeland, and McCaughrin, "Reference Guide to Us Repo and Securities Lending Markets," 8.

${ }^{131}$ Ibid., 8-10.

132 Ibid., 7.

${ }^{133}$ Ibid., 10.

134 Ibid.
} 
unwinding to the same party. The following figure ${ }^{135}$ shows a sharp drop on Lehman tri-party repo books even in U.S. Treasuries and assets which are normally deemed safe when the bank went bankrupt.

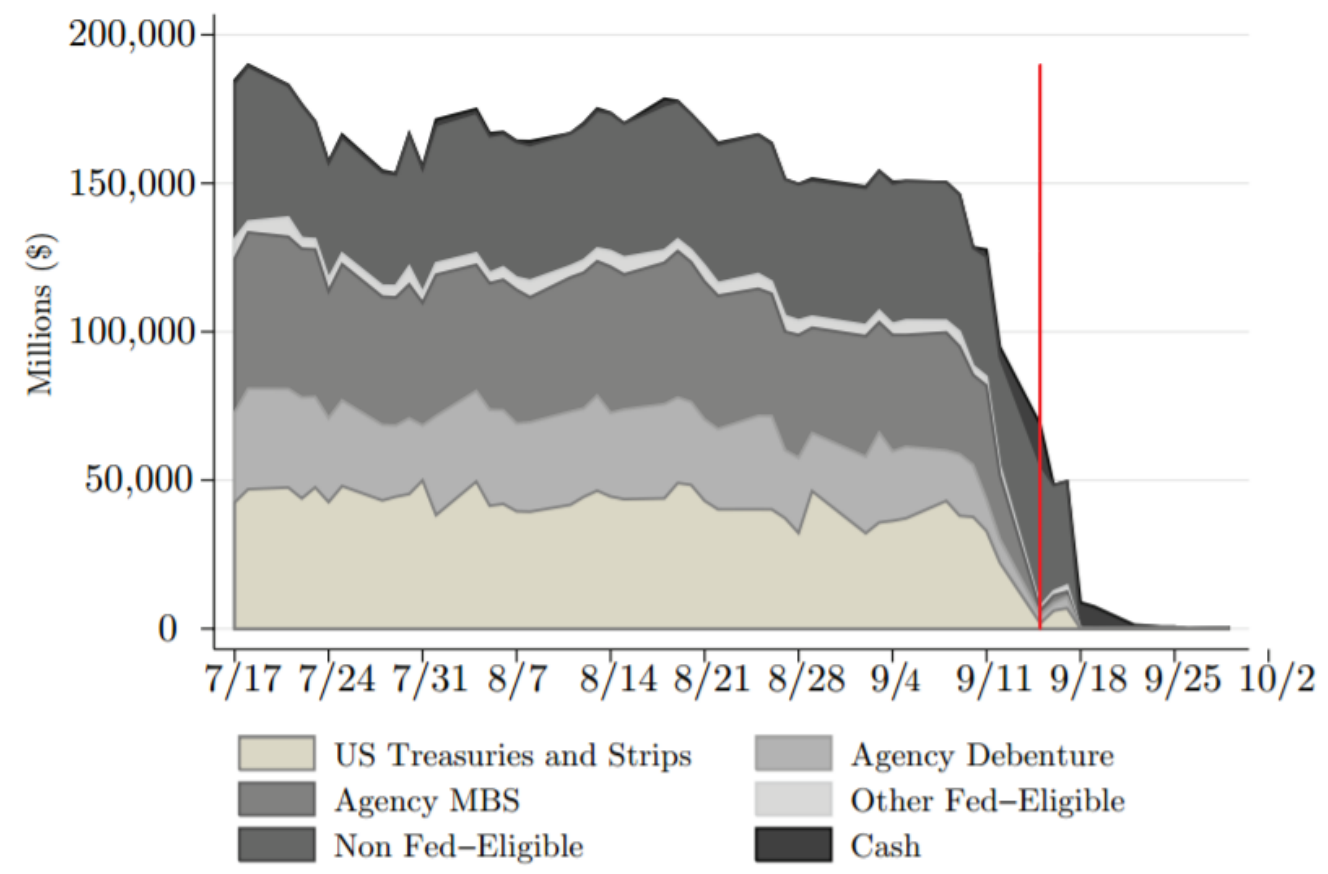

According to a recent report by the Financial Stability Oversight Council (FSOC), post-crisis reforms should be extended to the GCF Repos. The risk of collateral fire-sales by creditors of the defaulted broker-dealers remains a major financial stability concern. ${ }^{136}$ The Federal Reserve Bank of New York (FRBNY) has an interest in reforming the two clearing banks because they are operating other businesses as financial intermediaries and are subject to prudential regulation. ${ }^{137}$ Their exposure from clearing activity could therefore affect their banking business as well. It is also the responsibility of the Federal Reserve to supervise and regulate the banking industry in the U.S., to ensure its safety and soundness, and act as the lender of last resort to banks. In addition, the clearing banks and some dealers in this market

\footnotetext{
${ }^{135}$ Adam M Copeland, Antoine Martin, and Michael Walker, "The Tri-Party Repo Market before the 2010 Reforms," FRB of New York Staff Report, no. 477 (2010): 57.

${ }^{136}$ Financial Stability Oversight Council, "Financial Stability Oversight Council (Fsoc) 2016 Annual Report," (Washington, D.C.: Financial Stability Oversight Council, 2016), 111-12.

${ }^{137}$ For more information on this, see: https://www.newyorkfed.org/banking/tpr_infr_reform.html
} 
are systemically important. The dilemma before the regulators could be a classical one: the failure of a clearing bank could be unacceptable and catastrophic to the financial system, whereas bailing it out using the taxpayers' money could lead to moral hazard.

The U.S. system has therefore undergone a series of reforms since the crisis. In February 2012, a Tri-party Repo Infrastructure Reform Task Force set up by the New York Fed came up with a seven-point road map to recommend changes to the current operation model of the two clearing banks. As of November 2013, both clearing banks stopped providing intraday credit to facilitate the settlement of non-maturing trades and rolled trades. ${ }^{138}$ In May 2014, Bank of New York Mellon and J.P. Morgan Chase managed to restrict their intraday exposure to dealers to under $10 \%$ of the aggregate amount of all tri-party repos in the U.S. In June 2015, most of the reform goals were achieved. ${ }^{139}$

\section{Collateral management in Europe}

Tri-party repos play a relatively smaller part in the European repo markets mainly because it is not economic to outsource the collateral management to a third party. In addition to Bank of New York Mellon and JP Morgan, many national Central Securities Depositories (CSDs) are operating their own tri-party agents (e.g., Clearstream Banking Luxembourg/Frankfurt, Euroclear, SIX SIS in Switzerland, Monte Titoli in Italy, etc.,). These European tri-party repo agents do not typically expose themselves to the risk created by parties in repo transactions. In the event a default by a party, European tri-party agents simply cease further management of the collateral and await further instructions from the non-defaulting party. ${ }^{140}$ For the sake of being able to retrieve the collateral, most of the tri-party agents in Europe offer permanent right to substitution of the collateral but not re-use at the same time. ${ }^{141}$ Reverse repos are traditionally regarded as liquid assets in balance sheet due to the fact that the collateral can be

\footnotetext{
${ }^{138}$ https://www.newyorkfed.org/banking/tpr_infr_reform.html

${ }^{139}$ For detailed timetable, see https://www.newyorkfed.org/banking/tpr_infr_reform.html last visit: $4^{\text {th }}$ Feb. 2018.

${ }^{140}$ Comotto, "A Primer on Tri-Party Repo.", Subtitle 1, "What happens in a default?"

${ }^{141}$ Except for Swiss tri-party platform operated by XIS, see Ibid., Subtitle 2.
} 
rehypothecated at any time. Without the possibility to reuse the collateral, banks may face some obstacles at the regulatory level. To cope with this problem, re-use facilities are being established in Europe. The tri-party agents have access to the location of each piece of collateral when they need to substitute them. ${ }^{142}$

Regulatory reforms affecting securities financing transactions - especially the collateral used in such transactions - spans across a whole host of regulations having direct or indirect impact on repos. We have discussed some of the recent regulatory developments so far. In the next section, we will discuss some other major regulatory developments indirectly impacting repo markets.

\section{Basel III and the new developments in the regulation of repo markets}

The repo market is being increasingly regulated since the GFC. Investors have become more prudent in lending against highly rated assets without government backing, giving rise to a higher demand in the quality of collateral and a higher overall cost of credit. ${ }^{143}$ Recently, the European repo market has come under stress in terms of collateral shortage. The European Central Bank's (ECB) asset purchase program (APP) created liquidity, but also drove down lending rates, both for secured and unsecured lending. ${ }^{144}$

Rather counterintuitively, instead of the SFTR and FCD regimes, Basel III and its implementation in the EU by the Capital Requirements Directive (CRD IV) ${ }^{145}$ and the Capital Requirements Regulation (CRR) ${ }^{146}$ (jointly the so-called CRD IV Package) has perhaps had the most profound impact on the repo markets. The reforms of the risk-based capital

\footnotetext{
${ }^{142}$ Ibid., Subtitle 2.

${ }^{143}$ Peter Hördahl and Michael R King, "Developments in Repo Markets During the Financial Turmoil," BIS Quarterly Review (December 2008).

${ }^{144}$ Yves Mersch, "Ructions in the Repo Market - Monetary Easing or Regulatory Squeezing?: Speech by Yves Mersch, Member of the Executive Board of the Ecb, at the Gff Summit," (Luxembourg26 January 2017).

${ }^{145}$ Directive 2013/36/EU of the European Parliament and of the Council of 26 June 2013 on access to the activity of credit institutions and the prudential supervision of credit institutions and investment firms, amending Directive 2002/87/EC and repealing Directives 2006/48/EC and 2006/49/EC; OJ L 176, 27.6.2013

146 'Regulation (EU) No 575/2013 Of the European Parliament and of The Council of 26 June 2013 on prudential requirements for credit institutions and investment firms and amending Regulation (EU) No 648/2012.
} 
requirements, and the introduction of leverage ratio, liquidity coverage ratio (LCR) and net stable funding ratio (NSFR) all have a potential impact on repo markets in terms of increased cost of capital and liquidity for engaging in repo transactions. ${ }^{147}$

The impact is more dramatic in case of leverage ratio and LCR. ${ }^{148}$ As for the leverage ratio, Basel III proposes a non-risk-weighted leverage ratio set at $3 \%$ of tier 1 capital to total assets plus off-balance sheet exposures. The majority of repos are considered as a financial instrument with low risk and low return, because, traditionally, governmental bonds have a zero-risk weight. Implementing a non-risk-weighted leverage ratio means the same unit of reverse-repo bears the same amount of regulatory cost as unsecured loans, therefore it is much more expensive. In addition, a differentiation based on the quality of underlying collateral will not be directly considered under the new leverage ratio. Thus, the leverage ratio rule may encourage more risk-taking and therefore causing a decrease in repo business. ${ }^{149}$

Recent studies have found that pursuant to the introduction of the supplementary leverage ratio (SLR) in 2012 in the U.S., repo borrowings by broker-dealer affiliates of Bank Holding Companies (BHCs) $)^{150}$ has decreased, but the use of repo backed by more price-volatile collateral has increased. ${ }^{151}$ The evidence on this is far from conclusive. Some studies suggest risk shifting from broker-dealer affiliates of banks to those affiliated with non-banks and heightened amounts of risk due to the use of repo backed by more price-volatile collateral. ${ }^{152}$ In addition, there is evidence that broker-dealer affiliates of BHCs were discouraged from borrowing in triparty repo markets pursuant to the introduction of the leverage ratio. This development was concomitant with an increase in the activity of active nonbank-affiliated

\footnotetext{
${ }^{147}$ International Capital Markets Association, "Perspectives from the Eye of the Storm: The Current State and Future Evolution of the European Repo Market," (ICMA, 2015), 10.

${ }^{148}$ Ibid. For example, in addition, the calculations for the purpose of meeting the leverage ratio include leverage obtained through repo borrowing.

${ }^{149}$ See also CGFS (2015), 'Regulatory change and monetary policy', CGFS Papers No. 54, Committee on the Global Financial System, Bank for International Settlements, p. 7.

${ }^{150}$ As we know, Major broker dealers in the U.S. are a part of bank holding companies regulated by the Federal Reserve. For the complexities involved in the US bank holding structures, see Dafna Avraham, Patricia Selvaggi, and James Vickery, "A Structural View of Us Bank Holding Companies," FRBNY Economic Policy Review 18, no. 2 (2012). Fed 23A rule applies (Arm's length requirements, regulating the relationship between commercial banks and broker-dealer subsidiaries.)

${ }^{151}$ Meraj Allahrakha, Jill Cetina, and Benjamin Munyan, "Do Higher Capital Standards Always Reduce Bank Risk? The Impact of the Basel Leverage Ratio on the U.S. Triparty Repo Market," Office of Financial Research Working Paper (2016). 152 Ibid.
} 
dealers in certain asset classes entering triparty repo markets, suggesting a risk shifting behavior from the banking sector to non-bank sector. ${ }^{153}$ This increase in the importance of nonbank-affiliated broker-dealers in tri-party repo markets has been due to the more stringent capital requirements imposed on BHCs at a consolidated level. ${ }^{154}$

The LCR requirement, which will be fully implemented by 2019, stipulates that the bank should hold more high-quality liquid assets. Banks are therefore encouraged to switch to these assets at least at the end of each reporting period. The LCR of the Basel III makes it costlier for BHCs and their subsidiaries to rely on short-term repo funding with low-quality collateral. Basel III's NSFR is also adopted to encourage banks and their subsidiaries to rely more on the longer-term liabilities (with a maturity of over a year) and reduce their reliance on short-term wholesale funding. ${ }^{155}$

In 2011, the Federal Deposit Insurance Corporation (FDIC) expanded the deposit insurance assessment base from deposit to all of bank liabilities (including repos). This is expected to make it more expensive for insured banks to fund their assets in the repo markets. ${ }^{156}$ Section 165 and 166 of the Dodd-Frank Act (enhancing prudential standards for U.S. BHCs) also encourages the dealer subsidiaries of BHCs to shift more toward longer-term financing.

Although the size of repo markets remains substantial, overall the maturity of repo funding has been extended, especially for the repos with low-quality collateral. ${ }^{157}$ There has also been a move toward diversification of funding sources among dealers. ${ }^{158}$ Although U.S. dealers and

\footnotetext{
153 Ibid.

154 Ibid., 33.

${ }^{155}$ As a result of differentiated implementation of the Basel III in different jurisdictions, one might expect that divergence in the trend in the repo markets will be widened. Since in addition to supplementary leverage ratio (SLR) in the U.S., there will be an enhanced supplementary leverage ratio (eSLR) for Global Systemically Important Banks (GSIBs). It seems that repo markets will be shaped differently across the Atlantic in response to the implementation of Basel III requirements. In the EU, there is a GSIBs buffer, but it is risk-based. However, eSLR is risk neutral.

${ }^{156}$ Baklanova, Copeland, and McCaughrin, "Reference Guide to Us Repo and Securities Lending Markets," 33-37.

157 (see figure 14).

${ }^{158}$ For example, in December 2014, the top three dealers accounted for around 30 percent of the average daily volume in non- traditional triparty repo, down from nearly 50 percent in May 2010, when the Federal Reserve started publishing these statistics. See https://www.newyorkfed.org/data-and-statistics/data-visualization/tri-party-repo/index.html See Baklanova, Copeland, and McCaughrin, "Reference Guide to Us Repo and Securities Lending Markets," 33-37.
} 
banks have decreased their reliance on repo, for U.S.-based foreign bank offices, repo remains a substantial source of funding. This is mainly because of differences in regulations as well as the fact that those banks have a limited access to U.S. retail deposits. ${ }^{159}$

The reforms of the market infrastructure for repo and derivatives transactions will also affect the repo markets. This is expected to strengthen the risk management by tri-party repo cash investors by incenting them to accept more liquid and high-quality collateral, hence decreasing the counterparty risk. A trend towards more conservatively collateralized tri-party repo markets is expected which could lead to more conservative pricing of credit intermediation by tri-party repo markets. ${ }^{160}$ In sum, it seems that the implementation of Basel III will have an adverse effect on the incentives of banks to provide or receive funding through repo markets, thereby undermining the demand for short-term repo funding.

\section{Conclusion}

In spite of international efforts both by industry associations and international financial regulatory fora to harmonize and standardize the practices in repo markets, this paper uncovered significant divergences, differences and idiosyncrasies in the existing repo markets across the Atlantic. These differences span across a wide variety of issues, including legal underpinnings and structure of repo markets, repo terms, repo participants, the underlying collateral backing repos, and idiosyncrasies in the financial market infrastructure within which repos are being cleared and settled. Although the GFC provided a clear evidence that financial

\footnotetext{
${ }^{159}$ Indeed, since the first quarter of 2008, repo and fed funds liabilities of foreign bank offices in the U.S. have increased by over 20 percent, bringing their reliance on this type of funding to 18 percent of total liabilities as of the end of 2014 (see Figure 15). To address this anomaly, starting in mid-2016 the Federal Reserve's Regulation YY will require any foreign bank with $\$ 50$ billion or more in U.S. non- branch/agency assets to place all its U.S. subsidiaries within a U.S. intermediate holding company. The intermediate holding company will be subject to the same enhanced prudential standards as U.S. banks, including U.S. Basel III rules, capital planning, Dodd-Frank Act stress testing, liquidity, and risk management requirements." Ibid.

${ }^{160}$ Tobias Adrian and Adam B. Ashcraft, "Shadow Banking Regulation," Federal Reserve Bank of New York Staff Report, no. 559 (2012): 42.
} 
markets have converged and become homogenous, and virtually no issue could be dealt with separately, this should not lead international financial fora and national regulators to overlook such idiosyncrasies in their quest to promote financial stability. At the very least, the cognizance of such differences requires differentiated approaches to regulating repo markets.

Although the post-GFC regulatory reforms including the Dodd-Frank Act, the EMIR Regulation and a plethora of different legislative and regulatory measures, such as SFTR and BRRD in Europe, share the same objectives, which includes avoiding fire-sales, mitigating systemic risk, improving market transparency and ensuring the smooth operation of financial markets, the means to achieve those ends differ in significant ways across the Atlantic. Our findings suggest that even taking account of the post-GFC regulatory reforms in the EU and the U.S., the regulatory divergences in the repo markets persist, as manifested, for example, in the treatment of repos in the insolvency proceedings. The paper recounts a cautionary tale of the divergences, idiosyncrasies and differences in the global financial markets, which rally against the efforts to apply uniform rules and regulations at the international level to the markets replete with such salient idiosyncrasies and argues that such distinctions should not be swept under the rug by international fora having the mandate of promoting global financial stability. 


\section{Bibliography}

(AMF), Autorité des Marchés Financiers. "The Reuse of Assets: Regulatory and Economic Issues." (November 9, 2016).

(ICMA), International Capital Market Association. "European Repo Market Survey: Number 33 - Conducted June 2017." (October 2017).

. "European Repo Market Survey: Number 34- Conducted December 2017." (March 2018).

Acharya, Viral V., and T. Sabri Öncü. "A Proposal for the Resolution of Systemically Important Assets and Liabilities: The Case Ofthe Repo Market." International Journal of Central Banking 9, no. S1 (January 2013 2013): 291-349.

Adrian, Tobias, and Adam B. Ashcraft. "Shadow Banking Regulation." Federal Reserve Bank of New York Staff Report, no. 559 (2012).

AG, Eurex Clearing. "How to Get Started on Eurex Repo: Eurex Clearing Guidelinie." 6 November 2017.

Aitken, James, and Manmohan Singh. Deleveraging after Lehman--Evidence from Reduced Rehypothecation (Epub). Vol. 9: International Monetary Fund, 2009.

Allahrakha, Meraj, Jill Cetina, and Benjamin Munyan. "Do Higher Capital Standards Always Reduce Bank Risk? The Impact of the Basel Leverage Ratio on the U.S. Triparty Repo Market." Office of Financial Research Working Paper (November 10, 2016 2016).

Antinolfi, G., F. Carapella, C. Kahn, A. Martin, D. C. Mills, and E. Nosal. "Repos, Fire Sales, and Bankruptcy Policy." Review of Economic Dynamics 18, no. 1 (2015/01/01/ 2015): 21-31.

Association, International Capital Market. "Frequently Asked Questions on Repo." edited by International Capital Market Association (ICMA), 2015.

Association, International Capital Markets. "Perspectives from the Eye of the Storm: The Current State and Future Evolution of the European Repo Market." ICMA, 2015.

Authority, European Banking. "Eba Report on Eu Covered Bond Frameworks and Capital Treatment: Response to the Commission's Call for Advice of December 2013 Related to Article 503 of the Regulation (Eu) No 575/2013 and to the Esrb Recommendation E on the Funding of Credit Institutions of December 2012 (Esrb/12/2)." London, 01 July 2014.

Avraham, Dafna, Patricia Selvaggi, and James Vickery. "A Structural View of Us Bank Holding Companies." FRBNY Economic Policy Review 18, no. 2 (July 2012 2012): 65-81.

Baklanova, Viktoria, Adam Copeland, and Rebecca McCaughrin. "Reference Guide to Us Repo and Securities Lending Markets." In Federal Reserve Bank of New York Staff Reports. New York: Federal Reserve Bank of New York, 2015.

Baklanova, Viktoria, Ocean Dalton, and Stathis Tompaidis. "Benefits and Risks of Central Clearing in the Repo Market." Office of Financial Research Brief Series 17, no. 04 (2017): 2-8. 
Benjamin, Joanna, Guy Morton, and Michael Raffan. "The Future of Securities Financing." Law and Financial Markets Review 7, no. 1 (2013/01/28 2013): 4-8.

Bliss, Robert R., and George G. Kaufman. "Derivatives and Systemic Risk: Netting, Collateral, and Closeout." Journal of Financial Stability 2, no. 1 (4// 2006): 55-70.

Board, European Systemic Risk. "Esrb Opinion to Esma on Securities Financing Transactions and Leverage under Article 29 of the Sftr." 2016.

Board, Financial Stability. "Securities Lending and Repos: Market Overview and Financial Stability Issues- Interim Report of the Fsb Workstream on Securities Lending and Repos." Basel, Switzerland, 2012.

Claessens, Stijn, and Lev Ratnovski. "What Is Shadow Banking?". IMF Working Paper (2014).

Commission, The Financial Crisis Inquiry. "The Financial Crisis Inquiry Report: Final Report of the National Commission on the Causes of the Financial and Economic Crisis in the United States." Washington, D.C., 2011.

Comotto, Richard "A Primer on Tri-Party Repo." (2017).

Copeland, Adam, Darrell Duffie, Antoine Martin, and Susan McLaughlin. "Key Mechanics of the Us Tri-Party Repo Market." Federal Reserve Bank of New York Economic Policy Review 18, no. 3 (2012): 17-28.

Copeland, Adam M, Antoine Martin, and Michael Walker. "The Tri-Party Repo Market before the 2010 Reforms." FRB of New York Staff Report, no. 477 (2010).

Council, Financial Stability Oversight. "Financial Stability Oversight Council (Fsoc) 2016 Annual Report." Washington, D.C.: Financial Stability Oversight Council, 2016.

Duffie, Darrell. "The Failure Mechanics of Dealer Banks."

_. "The Failure Mechanics of Dealer Banks." Journal of Economic Perspectives 24, no. 1 (2010): 51-72.

Duffie, Darrell, and David A Skeel. "A Dialogue on the Costs and Benefits of Automatic Stays for Derivatives and Repurchase Agreements." (2012).

Duffie, Darrell, and Haoxiang Zhu. "Does a Central Clearing Counterparty Reduce Counterparty Risk?". The Review of Asset Pricing Studies 1, no. 1 (2011): 74-95.

Edwards, Franklin R, and Edward R Morrison. "Derivatives and the Bankruptcy Code: Why the Special Treatment." Yale Journal on Regulation 22 (2005): 91.

Faubus, Bryan G. "Narrowing the Bankruptcy Safe Harbor for Derivatives to Combat Systemic Risk." Duke Law Journal 59, no. 4 (2010): 801-42.

Fund, International Monetary. "Global Financial Stability Report: Risk Taking, Liquidity, and Shadow Banking: Curbing Excess While Promoting Growth." Washington, DC: International Monetary Fund, October 2014.

. "Global Financial Stability Report: The Quest for Lasting Stability." Washington, DC: International Monetary Fund, April 2012.

Gelpern, Anna, and Erik F. Gerding. "Rethinking the Law In "Safe Assets"." Chap. 9 In Reconceptualising Global Finance and Its Regulation, edited by Ross P. Buckley, Emilios Avgouleas and Douglas W. Arner, 159- 89. New York: Cambridge University Press, 2016. 
Goralnik, Nathan. "Bankruptcy-Proof Finance and the Supply of Liquidity." Yale Law Journal 122 (2012): 460-506.

Gorton, Gary. "Shadow Banking." The Region, December 2010, 16-29.

Gorton, Gary B. Slapped by the Invisible Hand: The Panic of 2007. New York: Oxford University Press, 2010.

Gorton, Gary B., and Andrew Metrick. "Regulating the Shadow Banking System." Brookings Papers on Economic Activity (2010): 261-312.

. "Securitized Banking and the Run on Repo." Journal of Financial Economics 104, no. 3 (2012): 425-51.

Gorton, Gary, Stefan Lewellen, and Andrew Metrick. "The Safe-Asset Share." The American Economic Review 102, no. 3 (2012): 101-06.

Harris, Daniel. "Use of Customer Securities by Uk Prime Brokers: The Road Ahead." Law and Financial Markets Review 7, no. 2 (2013/03/28 2013): 107-11.

Hördahl, Peter, and Michael R King. "Developments in Repo Markets During the Financial Turmoil." BIS Quarterly Review (December 2008).

Johnson, Christian A. "Derivatives and Rehypothecation Failure: It's 3:00 Pm, Do You Know Where Your Collateral Is?". Arizona Law Review 30 (1997): 949-1001.

Kirshner, Jodie A. "The Bankruptcy Safe Harbor in Light of Government Bailouts: Reifying the Significance of Bankruptcy as a Backstop to Financial Risk." NYUJ Legislation and Public Policy 18 (2015): 795-836.

Krishnamurthy, Arvind, Stefan Nagel, and Dmitry Orlov. "Sizing up Repo." The Journal of Finance 69, no. 6 (2014): 2381-417.

Lubben, Stephen J. "Derivatives and Bankruptcy: The Flawed Case for Special Treatment." University of Pennsylvania Journal of Business Law 12, no. 1 (2009): 61-78.

. "Repeal the Safe Harbors." American Bankruptcy Institute Law Review 18 (2010): 319-35.

. "The Bankruptcy Code without Safe Harbors." American Bankruptcy Law Journal 84 (2010): 123-44.

Mancini, Loriano, Angelo Ranaldo, and Jan Wrampelmeyer. "The Euro Interbank Repo Market." The Review of Financial Studies 29, no. 7 (2016): 1747-79.

Mersch, Yves. "Ructions in the Repo Market - Monetary Easing or Regulatory Squeezing?: Speech by Yves Mersch, Member of the Executive Board of the Ecb, at the Gff Summit." Luxembourg, 26 January 2017.

Michel, Norbert J. "Fixing the Regulatory Framework for Derivatives." Washington, D.C., 2016.

Mooney, Charles W. "The Bankruptcy Code's Safe Harbors for Settlement Payments and Securities Contracts: When Is Safe Too Safe?". Texas International Law Journal 49 (2014): 245-69.

Nabilou, Hossein, and Alessio Pacces. "The Law and Economics of Shadow Banking." In Research Handbook in Shadow Banking, edited by Iris H. Chiu, forthcoming 2017.

Norman, Peter. The Risk Controllers: Central Counterparty Clearing in Globalised Financial Markets. Chichester, West Sussex: John Wiley \& Sons, Ltd., 2011. 
Paech, Philipp. "Shadow Banking: Legal Issues of Collateral Assets and Insolvency Law." Brussels: European Parliament; Directorate General for Internal Policies; Policy Department A: Economics and Scientific Policy, 2013.

. "The Value of Insolvency Safe Harbours." LSE Legal Studies Working Paper No. 9/2015 (2015).

Pozsar, Zoltan. "Shadow Banking: The Money View." Office of Financial Research Working Paper (July 02, 2014 2014).

Saguato, Paolo. "The Liquidity Dilemma and the Repo Market: A Two-Step Policy Option to Address the Regulatory Void." Stan. JL Bus. \& Fin. 22 (2017): 85.

Schwarcz, Steven L. "Derivatives and Collateral: Balancing Remedies and Systemic Risk." University of Illinois Law Review 2015, no. 2 (2015): 699-720.

. "Distorting Legal Principles." Journal of Corporation Law 35, no. 4 (2010): 697-727.

Shleifer, Andrei. "Comments and Discussions (Regulating the Shadow Banking System by Gary Gorton \& Andrew Metrick)." Brookings Papers on Economic Activity (2010): 298-303.

Singh, Manmohan. "Velocity of Pledged Collateral: Analysis and Implications." IMF Working Paper WP/11/256 (2011).

Singh, Manmohan, and James Aitken. "The (Sizable) Role of Rehypothecation in the Shadow Banking System." IMF Working Paper 10/172 (2010).

Sissoko, Carolyn. "The Legal Foundations of Financial Collapse." Journal of Financial Economic Policy 2, no. 1 (2010): 5-34.

Skeel, David A., and Thomas H. Jackson. "Transaction Consistency and the New Finance in Bankruptcy." Columbia Law Review 112, no. 1 (2012): 152-202.

Stulz, René M. "Should We Fear Derivatives?". The Journal of Economic Perspectives 18, no. 3 (2004): 173-92.

Wymeersch, Eddy. "Shadow Banking and Systemic Risk." European Banking Institute Working Paper Series No. 1 (2017).

Yagiz, Bora. "Clearinghouses' Default "Waterfall” Offers No Panacea against Their Potential Failure." Regulatory Intelligence: Thomson Reuters (2014). 